\title{
Overview of the Characteristics of the Modular Industry and Barriers to its Increased Market Share in Canada
}

\author{
Tarek SALAMA 1 ,Osama MOSELHI², Mohamed AL-HUSSEIN³ \\ ${ }^{1}$ Assistant Professor, Department of Construction Management, California State University, Sacramento, California, US \\ ${ }^{2}$ Professor, Department of Building, Civil and Environmental Engineering, Concordia University, Montréal, Canada \\ ${ }^{3}$ Professor, Department of Civil and Environmental Engineering, University of Alberta, Canada
}

\author{
Submitted January 23, 2021 \\ Accepted May 31, 2021 \\ Published July 2021

\section{Corresponding Author \\ Tarek Salama, Ph.D \\ salama@csus.edu} \\ Department of Construction \\ Management, \\ California State University \\ 6000 J Street, Sacramento, CA \\ 95819
}

DOI

http://doi.org/10.29173/ijic249

Pages 30-53

ISSN 2563-5034

Distributed under Creative Commons CC-BY-NC-ND 4.0

\section{ABSTRACT}

Modular and offsite construction approaches reduce project duration and cost by synchronizing offsite and onsite work. Project activities are undertaken in a controlled offsite facility to minimize the effects of inclement weather and site disruptions, while meeting safety and quality requirements. To study the characteristics of modular and offsite construction, questionnaires have been conducted during the last decade by many organizations, including the Modular Building Institute (MBI), the Buildoffsite campaigning organization in the United Kingdom, the Canadian Manufactured Housing Institute, the National Institute of Building Sciences, McGraw-Hill Construction, and the Fails Management Institute. This paper introduces comprehensive analysis of the results of a questionnaire survey carried out in collaboration between members of the Department of Building, Civil \& Environmental Engineering at Concordia University, the Modular Building Institute, NRB Inc., and the Department of Civil \& Environmental Engineering at the University of Alberta. The questionnaire focuses on two issues: (1) the characteristics of the modular and offsite construction industry, and (2) the barriers against increased market share in this industry. For the latter, an effort was made to address a set of five factors identified in a workshop on the topic of challenges and opportunities for modular construction in Canada held in Montréal in 2015 to analyze barriers to growth of modular construction in the Canadian context. Key findings of this survey include requests for use of a separate building code for modular construction design, innovative financing and insurance solutions, standards that consider procurement regulations, and for financial institutions to create lending programs suited for modular construction.

\section{KEYWORDS}

Project delivery; Questionnaire; Survey; Barriers; Industry characteristics; Modular construction 


\section{Introduction}

Modular and offsite construction practices gained considerable momentum in recent years due to benefits of modularization and prefabrication such as reducing construction costs and schedules and improved safety and quality $[1,2]$. The term "modular" means "designed with standardized units or dimensions, for easy assembly and repair or flexible arrangement and use" [3]. The modular process is utilized in many fields such as heavy industrial plants, residential buildings, ships and submarines, and even in nuclear power plants known as small modular reactors (SMRs). The literature shows the use of diverse definitions and terminologies to describe offsite construction, including the following:

1- Modularization: "The preconstruction of a complete system away from the job site that is then transported to the site. Modules are large in size and possibly may need to be broken down into several smaller pieces for transport" [4-6].

2- Module: "A module is an essential and self-contained functional unit relative to the product of which it is part. The module has, relative to a system definition, standardized interfaces and interactions that allow composition of products by combination" " [4,7].

3- Prefabrication: "Manufacturing processes, generally taking place at specialized facility, in which various materials are joined to form a component part of a final installation" $[4,8]$.

4- Preassembly: "A process by which various material, prefabricated components and/or equipment are joined together at a remote location for subsequent installation as a unit. It is generally focused on a system" [8].

5- Offsite fabrication: "The practice of preassembly or fabrication of components both off the site and onsite at a location other than at the final installation location" [9].

6- PPMOF (prefabrication, preassembly, modularization, and offsite fabrication): Several manufacturing and installation techniques, which move many fabrication and installation activities from the plant site into a safer and more efficient environment [10].

One categorization approach depends on the size and complexity of manufactured components and on the amount of finishing work done in an offsite manufacturing facility and how much labor is required for on-site assembly [11]. Five categories/systems are described in this approach, as shown in Figure 1. These categories/systems are used to differentiate between different types of offsite construction starting with the category that requires the least offsite finishing work, as follows:
1- Modular construction, which includes threedimensional volumetric components that form a complete portion of the building $[5,12]$.

2- Hybrid construction, which is a combination of modular and panelized construction approaches where bathrooms and kitchens are manufactured as separate modules, and panels are used for the rest of the building $[5,12]$.

3- Panelized construction, which includes the production of a series of two-dimensional planar components/panels that form a shell of a building and that require more finishing work onsite than modular construction $[5,12]$.

4- Prefabricated components, such as windows, which include components that are manufactured of separate components that cannot be assembled on site $[5,12]$.

5- Processed material, such as lumber, which includes most manufactured building components (microlevel manufacturing) and components that are shipped to the site.

Modular construction has the highest Market share of offsite manufacturing among all the offsite construction systems. The proportion of offsite manufacturing for modular construction falls in the range of $60 \%$ to $70 \%$, as compared to $30 \%$ to $50 \%$ for hybrid construction, and $15 \%$ to $25 \%$ for panelized construction. The proportion of offsite manufacturing accounts for a reduction in construction time of between $50 \%$ and $60 \%$ for modular construction, $30 \%$ to $40 \%$ for hybrid construction, and $20 \%$ to $30 \%$ for panelized construction [12].

This paper presents a comprehensive analysis for a questionnaire conducted to investigate current practices and industry characteristics of modular and offsite construction. Next sections include: a literature review for relevant previous studies and questionnaires, a description for the questionnaire method and how it was conducted, a section for questionnaire results that describes industry characteristics, a section for questionnaire results that describes barriers to increased market share, and discussion and conclusion.

\section{Literature Review}

The present study builds on the foundation of previous studies investigating the characteristics of modular and offsite construction. The Buildoffsite campaigning organization promoted offsite construction in the United Kingdom by publishing the results of an industry survey for offsite construction to measure the contribution of the offsite industry to the gross domestic product of the United Kingdom and to understand the depth of its supply base [13]. 


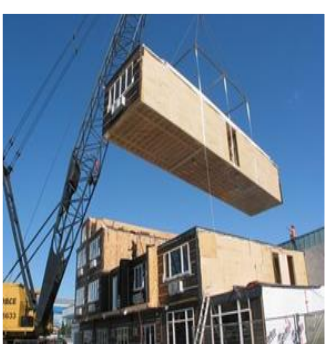

Modular construction

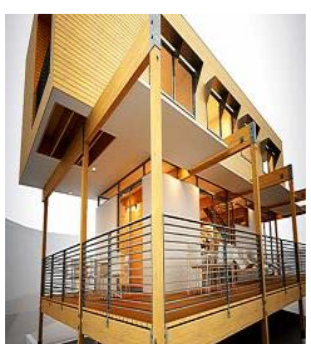

Hybrid construction

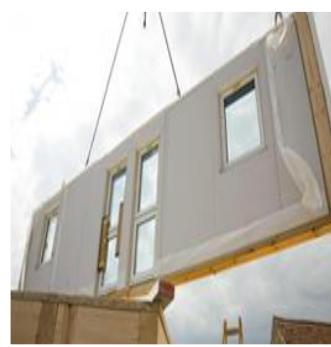

Panelized construction

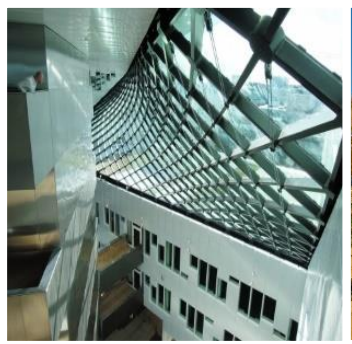

Prefabricated components

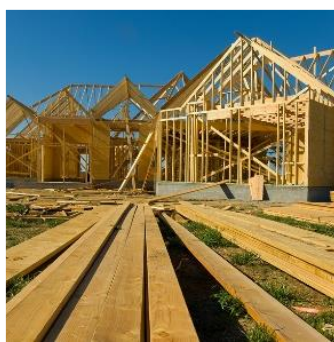

Processed material

Figure 1. Categories of offsite construction

Modular integrated construction laboratory (MiCLab) from University of Hong Kong presented publications that outlines the benefits, challenges, and successful case studies for modular construction [14,15]. The building and construction authority (BCA) in Singapore presented also interesting case studies and reports for design considerations and benefits of prefabricated prefinished volumetric construction (PPVC) [16]. Pan et al. [17] presented an investigation for barriers and drivers for offsite construction in the UK using a combination of questionnaire survey and personal interviews. It was concluded that traditional drivers such as cost, time, and quality are the main drivers for utilizing offsite construction, while current barriers include higher capital cost, long lead-in time, complex interfacing, and delayed planning process. Pan et al. [18] investigated practices of offsite construction using questionnaire survey, focus groups, and interviews to realize the benefits of offsite construction and how to integrate offsite processes at organizational level. McGraw-Hill Construction partnered with the Modular Building Institute (MBI), which is hereafter referred to be the industry partner in this paper, and the National Institute of Building Sciences (NIBS) among other collaborators to publish the results of a survey regarding prefabrication and modularization [19]. This report investigated the impact of prefabrication and modularization on productivity metrics such as project cost, schedule, quality, safety, and on the rate of green building certification, waste elimination, and utilization of building information modelling (BIM). The Fails Management Institute (FMI) published the results of a survey investigating prefabrication and modularization that included labor savings, market growth, return on investment (ROI), strategic marketing approach, benefits of prefabrication, annual sales, and factors driving prefabrication demand [20]. A report prepared by NIBS focused on annual revenues, project types, stakeholder collaboration, benefits of off-site construction, and barriers of implementing off-site construction [21]. Smith and Rice collaborated with the industry partner and NIBS to study offsite processes of modular construction by analyzing case studies [22,23]. These studies identify performance metric parameters for schedule, cost, risk, quality, safety, and scope, as well as compare modular to traditional construction to investigate added value, benefits, and barriers to implementing modular construction. The Canadian Manufactured Housing Institute (CMHI) conducted a survey for producers of factory-built homes to study the value of manufactured buildings in Canada, the volume of international trade for manufactured buildings, the annual construction investment by sector, the number of jobs generated by the manufactured building industry, the economic activity and impact, wages and business profits, and federal and provincial taxes for manufactured buildings [24]. Similarly, the industry partner prepares an analysis of the modular industry on a regular basis through its annual reports for permanent modular construction (PMC) and modular advantage publications $[3,25]$. The industry partner collects data internally from its members during the process of renewing annual memberships. The industry partner's data account for approximately $75 \%$ of industry assets and revenue in the relocatable buildings industry in North America [25]. The industry partner's reports focus on studying market share, growth forecasts, size of market, and production benchmarks. The 5-in-5 industry growth initiative introduced by the industry partner in 2015 was focused on increasing market share of the modular building industry in North America from $2.5 \%$ to $5 \%$ by 2020 . In North America, the modular building industry has increased from $2.37 \%$ of construction expenditure in 2014 to $3.17 \%$ in 2017, while the offsite construction share in the Japanese market is $12-15 \%$, and $50-90 \%$ in Sweden where panelized construction is dominating the market in 2018 [26]. In Australia, offsite construction as a whole is considered to be 5\% of total construction output with modular construction being considered the dominant method of offsite construction. Hence, the Melbourne School of Engineering at the University of Melbourne is leading an initiative to increase Australian offsite construction from $5 \%$ to $15 \%$ of total construction output by 2025 [26]. Smith and Quale [27] conducted a comparative analysis of the reports published by McGraw-Hill Construction, NIBS, and FMI, and provided quantitative and qualitative analyses for Smith and Rice's work [22,23]. Razkenari et al. [28] conducted a survey in the United States with the purpose of investigating the perception of industry 
experts regarding characteristics of offsite construction such as its demographic information, drivers, barriers, and possible solutions as well as a strengths, weaknesses, opportunities, and threats (SWOT) analysis to identify external and internal factors that are either favorable and unfavorable in terms of business models in offsite construction [28]. Dodge Data \& Analytics Inc. also introduced an important analysis of a survey conducted in collaboration with the industry partner to investigate prefabrication and modular construction trends, such as impact of prefabrication and BIM on cost, schedule, and project delivery method, as well as a forecast for building types using prefabrication in the next three years, and the drivers and obstacles of modular and offsite construction [29].

All told, these studies did not investigate some of current practices in modular construction such as project financing, standards and regulations, type of project delivery system, type of contracts, type of procurement method, synchronization of onsite and offsite schedules, BIM applications and software, scheduling software, and barriers to increased market share. Thus, this paper studies these practices and presents comprehensive analysis for the conducted questionnaire that was briefly introduced earlier since no thorough analysis was presented earlier for all the studied practices [30-32]. This paper also presents current efforts around the world dedicated to overcome the barriers and challenges facing modular and offsite construction and it investigates current practices and industry characteristics of modular construction in the context of the aforementioned gaps in the body of knowledge. Consequently, the authors hypothesize that the following five factors act as barriers to increased market share: negative stigma, shortage of examples of past success, standards and regulations, procurement strategies, and project financing. These five factors were discussed by industry professionals in a workshop with the intent to analyze barriers to growth of modular construction in Canada [33].

\section{Questionnaire method}

The authors of this study (from Concordia University and the University of Alberta) collaborated with the Modular Building Institute (MBI) and the Canadian Construction Association (then known as Canadian Construction Innovations) to host a workshop, entitled "Challenges and opportunities for modular construction in Canada," in October, 2015. This workshop was funded by Canam Group Inc. and the Natural Sciences and Engineering Research Council of Canada (NSERC) under its Engage and Connect programs, and it served to connect researchers with industry. Two panel sessions, the first intended for industry professionals and the second comprising academic researchers, were organized to discuss various perspectives related to the challenges and opportunities in modular and offsite construction. Attendees were divided into five groups, where each group was to discuss a specific topic in a round-table discussion for one hour based on their experience regarding the most important challenges for modular and offsite construction, and each table then presented their results and analysis and an open discussion took place among the attendees until the workshop concluded [33]. The five topics suggested by attendees were (1) negative stigma and marketing, (2) lack of evidence of past success, (3) standards and regulations, (4) procurement strategies, and (5) project financing. A research questionnaire was designed that contained two main parts. The first part was designed to capture the current practices in modular construction using 24 questions. These 24 questions cover the following topics:

- type of material used to describe the main material utilized to manufacture modules whether it is wood, steel, concrete, aluminum, GRP (glass fiber reinforced plastic), or polyurethane foam;

- type of produced modules to describe categories/systems utilized in offsite construction such as modular, hybrid, panelized, prefabricated components, or bathroom pods;

- type of modular construction project to describe which project type (medical, residential, commercial or institutional) is utilized for different project delivery systems (design bid build (DBB), design build (DB), integrated project delivery system (IPD), or construction management at risk (CMAR));

- volume of sales for modular construction of companies in the last 5 years;

- responsibility for activities of modular construction projects to describe which project stakeholder (modular company (manufacturer), general contractor, design firm) is responsible for construction activities such as manufacturing, transportation, site preparation, setting modules onsite, architectural design, etc.;

- scheduling software used to describe which scheduling software such as MS project, Primavera, excel sheets, simulation, or In-house is utilized for different project delivery systems such as DBB, DB, IPD, or CMAR;

- synchronization of onsite and offsite schedules to describe if onsite schedule is synced with sequence of manufacturing (offsite schedule) to establish the optimum overall schedule for material procurement, manufacturing, and onsite works;

- collecting productivity rates for onsite and offsite construction to describe practices of modular builders in collecting actual productivity rates for construction activities to build reliable schedules and to find any bottlenecks in manufacturing or onsite activities, type of project delivery systems utilized for modular construction projects such as: (1) (design bid build (DBB) system which is the traditional project delivery system where the owner has a contract with an 
architect to design and develop construction drawings and specifications, and another contract with a general contractor to construct the project, (2) design build (DB) system where the owner has only one contract with one entity responsible for design and construction, (3) integrated project delivery system (IPD) where the owner, architect, and general contractor are collaborating using a single contract to benefit from the knowledge of all project entities to reduce claims, or (4) construction management at risk (CMAR) where the owner hires a construction manager $(\mathrm{CM})$ who manages construction costs to deliver projects within a guaranteed maximum price (GMP);

- type of procurement method utilized for different project delivery systems such as: (1) best value procurement (BVP) which considers other factors than contract price, such as experience and quality and it allows for negotiations, (2) lowest bidder procurement which selects the contractor who provides the lowest price, (3) two envelopes procurement, which separate bids into two envelopes for price and technical proposals which are evaluated independently for procurement integrity, (4) procurement based on personal preference for different contractors;

- type of contracts utilized for different project delivery systems such as: (1) lump sum contracts which are traditional contracts that utilize a single price for the entire project, (2) cost plus fixed percentage contracts where the owner pays a percentage of the cost as a profit to the contractor, (3) cost plus incentive fee contracts where contractors are awarded incentive fee after achieving specific performance objectives, (4) guaranteed maximum price contracts where contractors are paid for actual costs plus a fixed fee with a maximum price, (5) time and materials contracts where contractors are paid for material costs, and their time on the job;

- square footage for modular projects relevant to different project delivery systems such as DBB, DB, IPD, or CMAR;

- difficulties in modular projects that should be highlighted to enhance this industry;

- distance between manufacturing facility and project construction site which was investigated by a range between a minimum and a maximum distance because these distances affect transportation cost of modules;

- average transportation cost per module square footage relevant to the reported minimum and maximum distances between manufacturing facility and project construction site;

- crane type utilized in lifting modules onsite whether they are crawler cranes, hydraulic trucks, or fixed tower cranes;

- daily placing rate for lifting and placing modules onsite by cranes to be assembled;
- average lifting capacity for cranes which determines modules' weight that can be handled onsite; and

- BIM applications and software to investigate current BIM software utilized in the market as well as its current applications such as rendering, structural analysis, and cost estimating, and to investigate which new applications can be utilized in the future such as virtual reality and $3 \mathrm{D}$ point clouds.

While the second part investigates barriers to increased market share, including a thorough investigation of the five specific topics previously discussed in the workshop. The questionnaire was available online using Google Forms starting April 16, 2017 until August 4, 2017, and 58 responses were received from 11 countries including Canada, the United States, the United Kingdom, China, Australia, New Zealand, Brazil, Russia, Slovenia, Saudi Arabia, and, the United Arab Emirates. Details about the expertise and experience of the participants are summarized in Table 1. The questionnaire was distributed to nearly 1,000 modular and offsite construction professionals using both LinkedIn messaging and email inviting them to participate and it provides anecdotal information about the industry in 2017. The questionnaire was conducted in an ethical manner, and a clear statement was provided to all respondents that the information collected will be treated strictly confidential and it will be used for academic research purposes.

Table 1. Background of respondents.

\begin{tabular}{|c|c|c|}
\hline & $\begin{array}{l}\text { Background of } \\
\text { respondents }\end{array}$ & $\begin{array}{c}\text { Percentage of } \\
\text { respondents }\end{array}$ \\
\hline \multirow{5}{*}{ Education } & $\begin{array}{l}\text { Bachelor of Science } \\
\text { (BSc.) }\end{array}$ & $65 \%$ \\
\hline & $\begin{array}{l}\text { Master of Science or } \\
\text { Engineering (MSc. } \\
\text { Or MEng.) }\end{array}$ & $10 \%$ \\
\hline & Master of Business & \\
\hline & $\begin{array}{l}\text { Administration } \\
\text { (MBA) }\end{array}$ & $15 \%$ \\
\hline & $\begin{array}{l}\text { Doctor of Philosophy } \\
\text { (PhD) }\end{array}$ & $10 \%$ \\
\hline \multirow{5}{*}{ Occupation } & $\begin{array}{l}\text { President or Vice- } \\
\text { president }\end{array}$ & $20 \%$ \\
\hline & $\begin{array}{l}\text { Chief Operations } \\
\text { Officer }\end{array}$ & $5 \%$ \\
\hline & Director & $30 \%$ \\
\hline & $\begin{array}{l}\text { Manager or Assistant } \\
\text { manager }\end{array}$ & $40 \%$ \\
\hline & Civil engineer & $5 \%$ \\
\hline \multirow{5}{*}{$\begin{array}{c}\text { Years of } \\
\text { experience }\end{array}$} & $0-10$ years & $15 \%$ \\
\hline & $10-20$ years & $25 \%$ \\
\hline & 20-30 years & $25 \%$ \\
\hline & $30-40$ years & $25 \%$ \\
\hline & $40-50$ years & $10 \%$ \\
\hline
\end{tabular}




\section{Industry characteristics}

This section provides a comprehensive analysis for the characteristics and current practices of modular and offsite construction relevant to the two main subjects that contributed to the $\mathrm{PhD}$ thesis of the first author of this paper [32] which are 1) the planning and scheduling by studying utilized scheduling software, delivery systems, scheduling features, and contract types. 2) Configuration for modular and offsite construction by studying type of modules and materials crane types, and transportation features.

\section{Type of modules and materials}

Modular construction proved to be the most common category of offsite construction. The percentage of respondents who indicated they are constructing modular, prefabricated components, panelized, and bathroom pods were $77.8 \%, 48.1 \%, 37.0 \%, 35.2 \%$, and $24.1 \%$, respectively as shown in Table 2 . Steel is dominant material type (79.6\% of respondents), compared to $63.0 \%$ and $27.8 \%$ for wood and concrete, respectively. Respondents also reported using emerging materials such as polyurethane foam panels, glass reinforced polymers (GRP), and aluminum (3.8\%, $1.9 \%$, and $1.9 \%$ of respondents, respectively).

\section{Type of modular construction project}

Respondents were asked to mention which type of modular construction project (medical, residential, commercial, or institutional) utilizes different delivery systems (DB, DBB, IPD, or CMAR). The highest percentage of utilizing a delivery system for medical buildings is for DB (22\% of respondents using DB use it for medical buildings) as shown in Table 3, while the lowest percentage of utilizing a delivery system for medical buildings is for DBB (11\% of respondents using DBB use it for medical buildings), This is likely explained by the fact that DB projects are using one entity to accomplish design and construction, and this is considered more suitable for complex projects like hospitals. The highest percentage of utilizing a delivery system for residential projects is for CMAR (40\% of respondents using CMAR use it for residential projects). While the highest percentage of utilizing a delivery system for commercial and institutional projects is for DBB (31\% of respondents using DBB use it for each of commercial and institutional projects).

\section{Volume of sales for modular construction}

By investigating volume of sales for modular construction reported by respondents only from 2012 until 2016, sales inclined for some companies while it declined for others as shown in Figure 2. However, the year-to-year percentage increase in sales has declined, as shown in Figure 3. The volume of sales increased from 2012 compared to 2013 for all the companies who responded to the questionnaire, and sales increased from 2013 to 2014 for only $50 \%$ of those companies.

Table 2. Type of modules and materials. Question Options and corresponding percentage of respondents

\begin{tabular}{lcccccc}
\hline Type of material in & Wood & Steel & Concrete & Aluminum & GRP & Polyurethane foam \\
fabrication of modules? & $63 \%$ & $79.6 \%$ & $27.8 \%$ & $1.9 \%$ & $1.9 \%$ & $3.8 \%$ \\
\hline Type of modules you & Modular & Panelized & Hybrid & Prefabricated components & Bathroom pods & Modular \\
produce? & $77.8 \%$ & $37 \%$ & $35.2 \%$ & $48.1 \%$ & $24.1 \%$ & $77.8 \%$ \\
\hline
\end{tabular}

Table 3. Type of modular construction project. Question

Options and corresponding percentage of respondents

Type of modular construction project?

\begin{tabular}{ccccc} 
Criteria & Medical & Residential & Commercial & Institutional \\
\hline DBB & $11 \%$ & $27 \%$ & $31 \%$ & $31 \%$ \\
\hline DB & $22 \%$ & $25 \%$ & $28 \%$ & $25 \%$ \\
\hline IPD & $18 \%$ & $30 \%$ & $29 \%$ & $23 \%$ \\
\hline CMAR & $20 \%$ & $40 \%$ & $20 \%$ & $20 \%$ \\
\hline
\end{tabular}

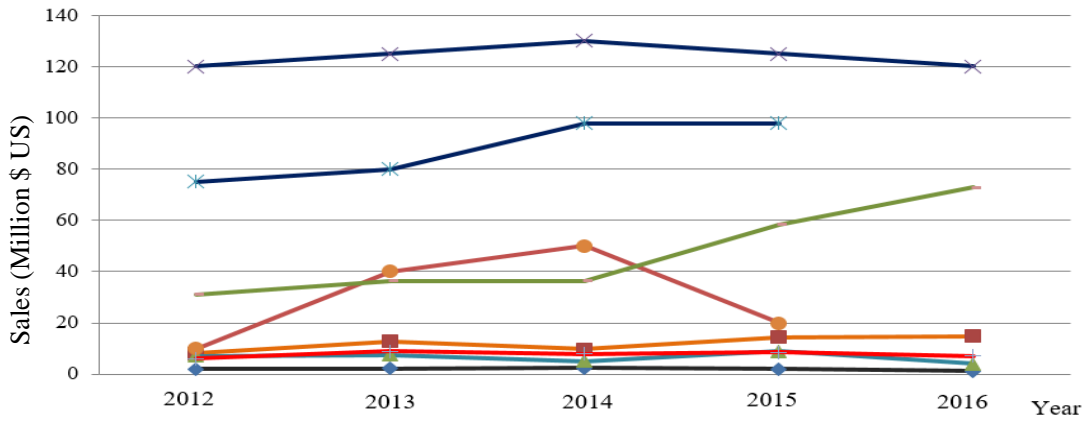

Figure 2. Volume of sales from 2012 until 2016 [31]. 


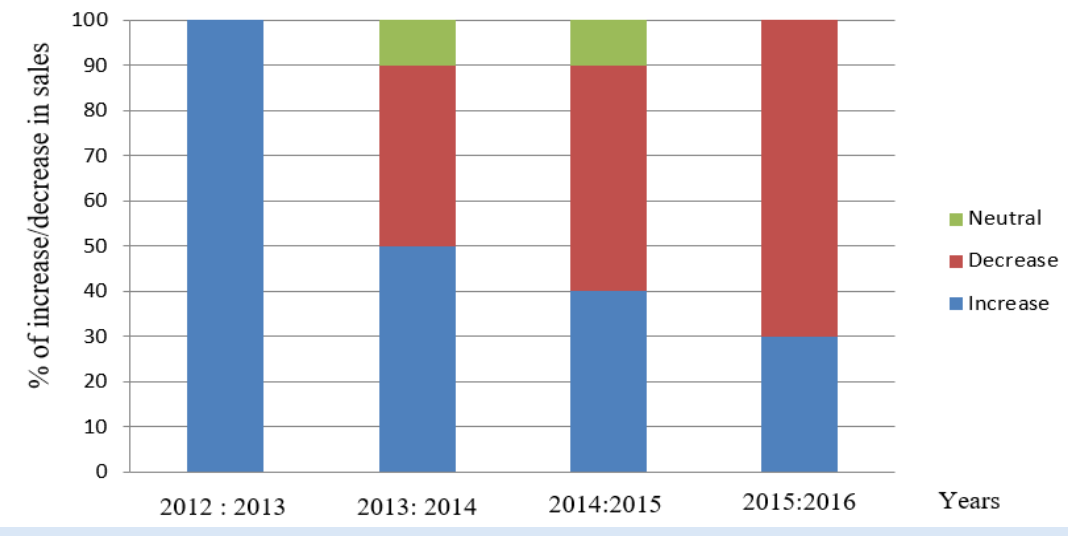

Figure 3. Year to year percentage of sales increase/decrease [31].

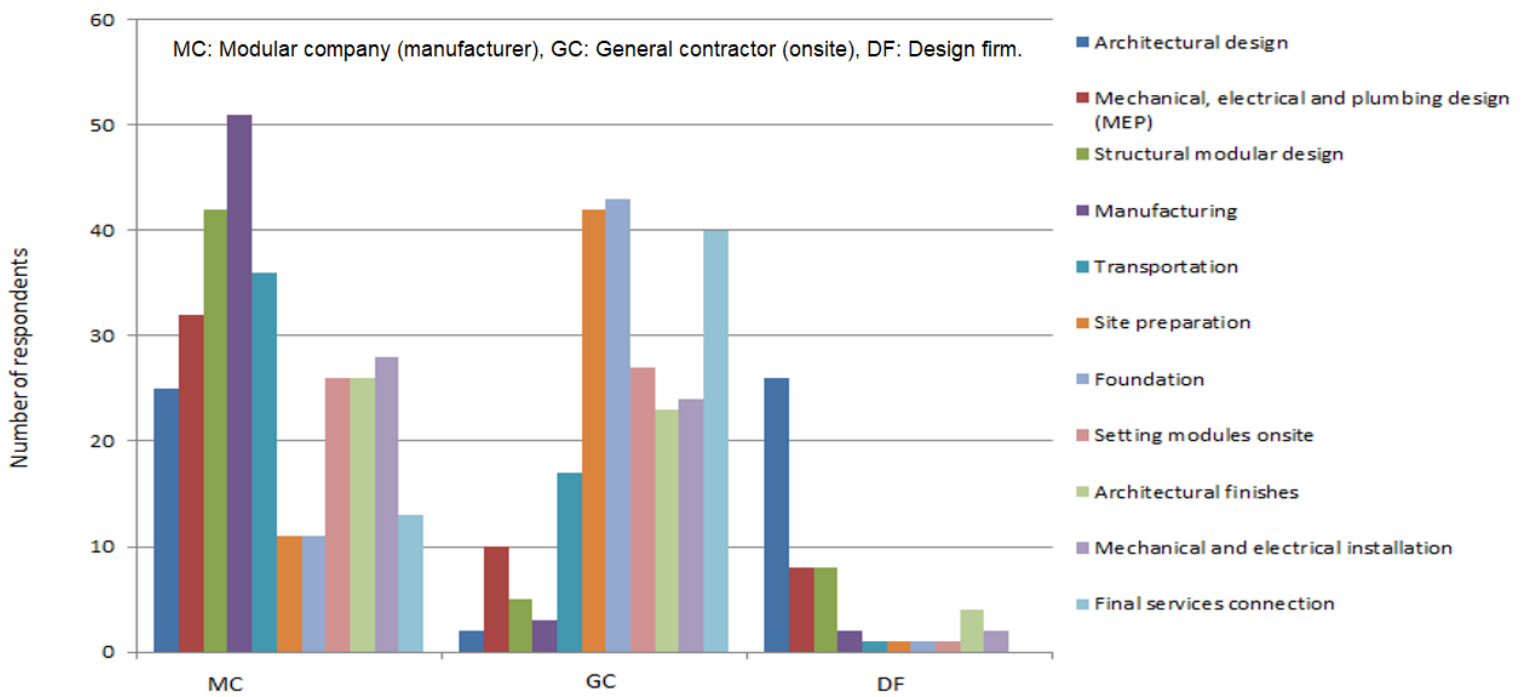

Figure 4. Division of responsibility for the various activities involved in modular projects [31].

\section{Main responsibilities of stakeholders for modular construction}

By investigating the main responsibilities of stakeholders for accomplishing the various activities involved in modular projects, the main responsibilities of the modular company/ manufacturer are manufacturing, structural modular design, and transportation of modules, while the main responsibilities of the general contractor are construction of the foundation, site preparation, and establishing final service connections for utilities such as water, gas, and electricity, as shown in Figure 4. The main responsibilities of design firms are architectural, structural, mechanical, electrical, and plumbing designs. However, the new trend among modular and offsite construction companies is to establish an integrated supply chain using one entity to develop, design, and build in order to enhance interoperability of their operations. This business model is already employed by Factory OS and Katerra in the United States, by
Lindbacks in Sweden, by Sekisui Heim in Japan, and by Lend Lease in Australia [34].

\section{Characteristics of cranes for modular construction}

Nearly half of survey responses indicate that the daily placing rate for modules onsite (lifted modules per day) ranges from five to ten modules, as shown in Table 4, while types of cranes used include hydraulic truck cranes, crawler cranes, and fixed tower cranes at $49.7 \%, 30.8 \%$, and $19.5 \%$ of responses, respectively. The average lifting capacity of cranes was determined to range from 25 to 50 tons according to $30 \%$ of respondents, while $20 \%$ of respondents indicated that crane capacity is less than 25 tons. Respondents employing a DBB delivery system indicated that $91 \%$ of their projects employ slings for module hoisting and $9 \%$ use lugs, while $55 \%$ of projects that employ a DB delivery system use slings and $45 \%$ use lugs as shown in Table 4. 
Table 4. Characteristics of cranes for modular construction.

Questions

\begin{tabular}{|c|c|c|c|c|c|}
\hline \multirow{2}{*}{$\begin{array}{l}\text { How many modules do the cranes lift per } \\
\text { day onsite (i.e., daily placing rate)? }\end{array}$} & $0-5$ & $5-10$ & $10-15$ & \multicolumn{2}{|c|}{$15-25$} \\
\hline & $11 \%$ & $51 \%$ & $16 \%$ & & \\
\hline $\begin{array}{l}\text { What is commonly used crane type in } \\
\text { lifting modules on your projects? }\end{array}$ & $\begin{array}{c}\text { Crawler crane } \\
30.8 \%\end{array}$ & $\begin{array}{l}\text { Hydraulic truck } \\
\quad 49.7 \%\end{array}$ & & $\begin{array}{l}\text { Fixed tower } \\
19.5 \%\end{array}$ & \\
\hline $\begin{array}{l}\text { What is the average lifting capacity of the } \\
\text { crane used? }\end{array}$ & $\begin{array}{c}0-25 \\
\text { metric ton } \\
20.8 \%\end{array}$ & $\begin{array}{c}25-50 \\
\text { metric ton } \\
30.2 \%\end{array}$ & $\begin{array}{c}50-75 \\
\text { metric ton } \\
19 \%\end{array}$ & $\begin{array}{c}75-100 \\
\text { metric ton } \\
15 \%\end{array}$ & $\begin{array}{c}>100 \\
\text { metric ton } \\
15 \%\end{array}$ \\
\hline How is the module hoisted? & & & & $\begin{array}{c}\text { Lugs } \\
9 \% \\
45 \% \\
31 \% \\
50 \%\end{array}$ & \\
\hline
\end{tabular}

Table 5. Types of Delivery Systems for modular construction.

Questions

\begin{tabular}{rcccc}
\hline Which project delivery & DBB & DB & IPD & CMAR \\
system is commonly used? & $22.4 \%$ & $44.9 \%$ & $28.6 \%$ & $4.1 \%$ \\
\hline What is the commonly used & Best value & Lower bidder & Two envelopes & Personal \\
procurement method? & $67 \%$ & $33 \%$ & - & - \\
DBB & $70 \%$ & $22 \%$ & $4 \%$ & $4 \%$ \\
DB & $85 \%$ & - & $7.5 \%$ & $7.5 \%$ \\
IPD & $50 \%$ & $50 \%$ & - & - \\
CMAR & $50 \%$ & &
\end{tabular}

Types of delivery systems for modular construction

The majority of modular and offsite projects employ the design-build (DB) method as their project delivery system as shown in Table 5 [32]. This result is aligned with the conclusions of Smith [26] that DB facilitates the early decision making which is required by modular construction practitioners to improve constructability and coordination. The use of DBB delivery system has declined steadily, while the integrated project delivery (IPD) system is emerging [35]. Logical results were drawn from comparing investigated characteristics based on percentage of responses for $\mathrm{DB}, \mathrm{DBB}$, and IPD, while the low number of responses for construction management at risk (CMAR) did not allow for comparing its results. For example, the percentage of respondents using a best value procurement (BVP), which combines two envelopes procedure plus negotiations is the highest in IPD as shown in Table 5 because BVP considers other factors than the bidding price, such as experience and quality to determine the bid that provides the best value. Choosing contractors based on the best value they provide reduces conflicts and claims as required by IPD contracts due to the better experience and quality provided by these contractors, while no lower bidder procedure is used with IPD and no personal bidding is used with DBB because DBB contracts are based on competitiveness [32].

\section{Scheduling features for modular construction}

Results of this questionnaire indicate a relationship between the utilized delivery method and scheduling features since the percentage of respondents using
Microsoft Project for scheduling, i.e., 65\%, 57\%, and $46 \%$ for IPD, DB, and DBB, respectively as shown in Table 6 [32]. The relative popularity of Microsoft Project is due to its capacity to increase interoperability among project stakeholders, which is needed to a more significant degree in IPD. The importance of adequate scheduling is investigated by studying the synchronization of offsite and onsite schedules and by collecting productivity rates of offsite and onsite operations. The percentage of responses who synchronize schedules is $87 \%, 82 \%$, and $72 \%$ for those respondents using IPD, DB, and DBB delivery systems, respectively and this result indicates that $87 \%$ of IPD users synchronize schedules for adequate scheduling compared to lower percentages for users of $\mathrm{DB}$, and $\mathrm{DBB}$ because IPD needs better coordination and scheduling. Productivity rates are collected for both offsite and onsite schedules by $73 \%, 61 \%$, and $28 \%$ of respondents using IPD, DB, and DBB delivery systems, respectively. Together, this indicates that IPD contracts have the best scheduling features that fit the shorter schedules of modular construction [32].

Contracts types for different project delivery systems utilized in modular construction

The percentage of respondents employing lump sum contracts for modular construction projects are 64\%, $85 \%$, and $80 \%$ for IPD, DB, and $\mathrm{DBB}$, respectively as shown in Table 7, and the higher percentage of respondents using traditional delivery systems in the context of DBB and DB compared to IPD is due to the fact that lump sum contracts better suit the traditional 
delivery systems. The percentage of respondents using cost-plus-fixed-percentage contracts was $21 \%$ and $10 \%$ for IPD and DBB, respectively, because the main idea behind the IPD delivery system is to use economic incentives by sharing rewards and risks to reduce claims among IPD team members. The only delivery system in this investigation that was reported to use cost-plusincentive-fee contracts with modular construction is also the IPD for the same reason, while the only delivery system to employ time-and-materials contracts is DBB.

\section{Total square footage of modular projects}

DBB projects were the most common among those with a total square footage between $100,000 \mathrm{sq} \mathrm{ft}$ and 200,000 $\mathrm{sq} \mathrm{ft}$, and for those with square footage greater than $200,000 \mathrm{sq} \mathrm{ft}$. This can be attributed to the use of DBB for governmental and institutional buildings such as hospitals and schools. While companies constructing buildings with square footage less than $50,000 \mathrm{sq} \mathrm{ft}$ were most often employing IPD and DB systems as shown in Table 8.

Obstacles and difficulties of modular projects

The obstacles and difficulties faced by modular builders are ranked as follows according to how frequently they were reported by respondents: (1) contractors are not experienced enough in applying modularization concepts $(61.5 \%)$, (2) the design scope was not frozen early in project schedule $(50 \%)$, (3) onsite and offsite schedules were not synchronized $(34.6 \%)$, (4) module envelope limitations (dimensional limitations) restricted the architectural design $(32.7 \%)$, (5) the scheduling method used was not suitable for the project $(7.7 \%)$, (6) the selected project delivery system was not suitable for the project $(5.8 \%)$, and (7) the attitudes of public inspectors $(1.9 \%)$.

Table 6. Scheduling features for modular construction.

\begin{tabular}{|c|c|c|c|c|c|c|}
\hline \multirow{2}{*}{$\begin{array}{l}\text { Questions } \\
\text { What is the scheduling software/method used in your } \\
\text { company? }\end{array}$} & \multicolumn{6}{|c|}{ Options and corresponding percentage of respondents } \\
\hline & $\begin{array}{c}\text { MS } \\
\text { Project }\end{array}$ & Excel & Primavera & Simulation & In-house & Other \\
\hline DBB & $46 \%$ & - & $23 \%$ & $23 \%$ & $8 \%$ & - \\
\hline DB & $57 \%$ & $10 \%$ & $21 \%$ & - & $4 \%$ & $8 \%$ \\
\hline IPD & $65 \%$ & - & - & $24 \%$ & - & $11 \%$ \\
\hline CMAR & $100 \%$ & - & - & - & - & - \\
\hline $\begin{array}{l}\text { Are the onsite and offsite schedules synchronized in your } \\
\text { project? }\end{array}$ & Yes & No & & & & \\
\hline DBB & $72 \%$ & $28 \%$ & & & & \\
\hline DB & $82 \%$ & $18 \%$ & & & & \\
\hline IPD & $87 \%$ & $13 \%$ & & & & \\
\hline CMAR & $100 \%$ & - & & & & \\
\hline $\begin{array}{l}\text { Was there a time study conducted to calculate productivity } \\
\text { rates for your offsite and/or onsite operations? }\end{array}$ & $\begin{array}{l}\text { Offsite } \\
\text { schedule }\end{array}$ & $\begin{array}{l}\text { Onsite } \\
\text { schedule }\end{array}$ & \multicolumn{2}{|c|}{$\begin{array}{l}\text { Both onsite and } \\
\text { offsite schedules }\end{array}$} & None & \\
\hline 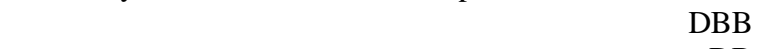 & $36 \%$ & - & $28 \%$ & & $36 \%$ & \\
\hline DB & $13 \%$ & $13 \%$ & $61 \%$ & & $13 \%$ & \\
\hline IPD & $7 \%$ & $7 \%$ & $73 \%$ & & $13 \%$ & \\
\hline CMAR & - & - & $50 \%$ & & $50 \%$ & \\
\hline
\end{tabular}

Table 7. Contracts types for different project delivery systems utilized in modular construction.

\begin{tabular}{|c|c|c|c|c|c|}
\hline \multirow{2}{*}{$\begin{array}{l}\text { Question } \\
\text { Which type of contracts is commonly used? }\end{array}$} & \multicolumn{5}{|c|}{ Options and corresponding percentage of respondents } \\
\hline & Lump sum & $\begin{array}{l}\text { Cost }+ \text { fixed } \\
\text { percentage }\end{array}$ & $\begin{array}{c}\text { Cost }+ \\
\text { incentive fee }\end{array}$ & $\begin{array}{c}\text { Guaranteed } \\
\text { maximum price }\end{array}$ & $\begin{array}{r}\text { Time \& } \\
\text { materials }\end{array}$ \\
\hline DBB & $80 \%$ & $10 \%$ & - & - & $10 \%$ \\
\hline DB & $85 \%$ & - & - & $15 \%$ & - \\
\hline IPD & $64 \%$ & $21 \%$ & $7.5 \%$ & $7.5 \%$ & - \\
\hline CMAR & $50 \%$ & $50 \%$ & - & - & - \\
\hline
\end{tabular}

Table 8. Total square footage of modular projects.

\begin{tabular}{|c|c|c|c|}
\hline Question & \multicolumn{3}{|c|}{ Options and corresponding percentage of respondents } \\
\hline What is the total square footage of your project? & $0-50,000 \mathrm{sq} \mathrm{ft}$ & $100,000-200,000 \mathrm{sq} \mathrm{ft}$ & $>200,000 \mathrm{sq} \mathrm{ft}$ \\
\hline DBB & $42 \%$ & $29 \%$ & $29 \%$ \\
\hline DB & $81 \%$ & $6.5 \%$ & $12.5 \%$ \\
\hline IPD & $82 \%$ & $9 \%$ & $9 \%$ \\
\hline CMAR & $100 \%$ & 0 & 0 \\
\hline
\end{tabular}


Table 9. Transportation cost and distance between manufacturing facility and project construction site.

\begin{tabular}{|c|c|c|c|c|c|c|c|}
\hline \multirow{2}{*}{$\begin{array}{l}\text { Questions } \\
\text { What is the typical distance between manufacturing facility and } \\
\text { project construction site? }\end{array}$} & \multicolumn{7}{|c|}{ Options and percentage of respondents } \\
\hline & $\begin{array}{c}0-50 \\
\mathrm{~km}\end{array}$ & $\begin{array}{l}50- \\
100 \\
\mathrm{~km}\end{array}$ & $\begin{array}{c}100- \\
200 \mathrm{~km}\end{array}$ & $\begin{array}{c}200- \\
500 \\
\mathrm{~km}\end{array}$ & $\begin{array}{c}500- \\
1000 \\
\mathrm{~km}\end{array}$ & $\begin{array}{c}1000- \\
5000 \\
\mathrm{~km}\end{array}$ & $\begin{array}{c}5000- \\
10000 \\
\mathrm{~km}\end{array}$ \\
\hline Minimum distance & $47 \%$ & $18 \%$ & $15 \%$ & $21 \%$ & - & - & - \\
\hline Maximum distance & $3 \%$ & $17 \%$ & $3 \%$ & $27 \%$ & $17 \%$ & $27 \%$ & $7 \%$ \\
\hline rtation cost per module square footage? & $\$ 0-\$ 2$ & $\$ 2-\$ 4$ & $\$ 4-\$ 10$ & $\$ 10$ & & $\$ 20$ & $-\$ 40$ \\
\hline Minimum distance & $\begin{array}{l}57 \% \\
10 \%\end{array}$ & $21 \%$ & $14 \%$ & & & & \\
\hline
\end{tabular}

Transportation cost and distance between manufacturing facility and project construction site

The most frequently reported distance between manufacturing facility and construction site is shown in Table 9 as both minimum distance and maximum distance, as well as the average transportation costs per square footage of the module. Regarding the distance between manufacturing facility and project construction site, $47 \%$ of respondents indicated that the minimum distance is less than $50 \mathrm{~km}$, while $27 \%$ of respondents indicated that the maximum distance is between $200 \mathrm{~km}$ and $500 \mathrm{~km}$, and another $27 \%$ of respondents indicated it is between 1,000 and $5,000 \mathrm{~km}$, as shown in Table 9 . Regarding the average transportation cost per module square footage, $57 \%$ of respondents reported that it is less than \$2 per square foot for the minimum transportation distance, while $50 \%$ of respondents reported that the transportation cost is between $\$ 4$ per square foot and $\$ 10$ per square foot for the maximum transportation distance.

\section{BIM features for modular projects}

Due to the need for better collaboration among project stakeholders for IPD contracts, the percentage of respondents employing building information modelling
(BIM) is highest for those respondents using the IPD delivery system at 57\%, with $48 \%$ and 50\% using BIM in DB and DBB, respectively as shown in Table 10, and the use of popular BIM software facilitates this collaboration. Revit was reported as being the most commonly used BIM software in modular construction projects at $64 \%$, $61 \%$, and $56 \%$ of respondents for IPD, DB, and DBB, respectively. BIM-based applications are ranked as follows according how respondents reported using them: (1) rendering for sales $(69.2 \%)$, (2) structural analysis (65.4\%), (3) cost estimation (53.8\%), (4) clash detection $(53.8 \%)$, (5) scheduling (50\%), and (6) heat analysis (23.1\%). Regarding BIM utilization in different project phases, $92 \%, 40 \%$, and $28 \%$ of respondents indicated that $\mathrm{BIM}$ is used for design, computer numeric control (CNC) of manufacturing processes, and monitoring onsite activities, respectively. Nearly half of respondents clarified that computer numeric control (CNC) of manufacturing processes and virtual reality (VR) headsets are being considered for future application in their operations. While $42 \%, 42 \%$, and $28 \%$ of respondents consider radio-frequency identification (RFID), 3D printing, and 3D point cloud technologies, respectively, as being under consideration for future applications.

Table 10. BIM features for modular projects.

\begin{tabular}{|c|c|c|c|c|c|c|}
\hline \multirow{2}{*}{$\begin{array}{l}\text { Questions } \\
\text { Is BIM used by your company? }\end{array}$} & \multicolumn{6}{|c|}{ Options and corresponding percentage of respondents } \\
\hline & Yes & No & & & & \\
\hline DB & $48 \%$ & $52 \%$ & & & & \\
\hline CMAR & $50 \%$ & $50 \%$ & & & & \\
\hline Which BIM software system is used by your company? & Revit & Bentley & ArchiCAD & SketchUp & Inventor & Other \\
\hline IPD & $64 \%$ & $9 \%$ & $27 \%$ & - & - & - \\
\hline $\begin{array}{l}\text { What BIM-based applications are used by your } \\
\text { company? }\end{array}$ & $\begin{array}{c}\text { Rendering } \\
\text { for sales } \\
69.2 \%\end{array}$ & $\begin{array}{c}\text { Structural } \\
\text { analysis } \\
65.4 \%\end{array}$ & $\begin{array}{c}\text { Cost } \\
\text { estimation } \\
53.8 \%\end{array}$ & $\begin{array}{c}\text { Clash } \\
\text { detection } \\
53.8 \%\end{array}$ & $\begin{array}{l}\text { Scheduling } \\
50 \%\end{array}$ & $\begin{array}{c}\text { Heat } \\
\text { analysis } \\
23.1 \%\end{array}$ \\
\hline Your company uses BIM in which project phase? & Design & Comput & $\begin{array}{l}\text { ter numeric contro } \\
\qquad(\mathrm{CNC})\end{array}$ & \multicolumn{3}{|c|}{ Monitoring for onsite activities } \\
\hline
\end{tabular}




\section{Barriers to increased market share}

This section describes results of the questionnaire based on the five factors determined by industry professionals as follows:

First hypothesis: Negative stigma is a barrier to increased market share

As shown in Figure 5, more than half of respondents agreed that there is negative stigma associated with modular construction, which can be attributed to the misconception that modular is intended primarily for temporary, single-storey applications. The percentage of respondents who agreed that the significant advantages of modular construction are not effectively communicated with owners is $70 \%$, while $80 \%$ of respondents agreed that there is a lack of well-designed marketing campaigns conducted by modular institutions and manufacturers, and $90 \%$ of respondents agreed that owners are not familiar with the various products offered by the modular industry [30]. While $81.5 \%$ of respondents agreed that the modular industry lacks large-scale partnerships and corresponding market share due to the focus of modular manufacturers on local markets, there is also consensus that a lack of academic research highlighting the advantages of modular construction is a factor $(83.6 \%$ of respondents, as shown in Figure 6). Moreover, $83.6 \%$ of respondents agreed with the suggestion that modular manufacturers and institutions organize regular facility visits for the public in order to increase awareness. To contribute to removing the stigma of modular construction, respondents agreed with the importance of the following recommendations in the context of the work carried out by the industry partner, PreFab Australia, and PreFab New Zealand: (1) promotional activities such as formal campaigns (66\% of responses), (2) establishing partnerships among manufacturers (62.3\%), organizing special workshops (52.8\%), communicating with authorities to have the building codes changed to improve industry standards among manufacturers (5.7\%), (5) establishing specialized courses for architects and students (3.8\%), (6) disclosing cost and schedule savings studies and optimization due to utilizing modular construction (3.8\%), and (7) increasing the use of automated systems (1.9\%). To further remove the negative stigma associated with modular construction, respondents agreed that the following recommendations should be undertaken by research institutes and universities: (1) organize workshops with industry practitioners, architects, government officials, and students (83\% of responses), (2) design courses that account for architectural aspects of modular construction (77.4\%), (3) provide courses for more exposure (64.2\%), (4) communicate with governments (1.9\%), and (5) evaluate the benefits of modular construction (1.9\%). Respondents requested specialized conferences, such as the Modular and Offsite Construction (MOC) Summit and the World of Modular, to encourage international cooperation among all parties in the modular construction industry to showcase American and Canadian advancements to the European industry and vice versa, and to document the outcomes in an open source format so that everyone has access to the information. It was also suggested that seminars and workshops could be conducted through non-governmental organizations, governmental bodies, and local communities, in addition to establishing advertisement campaigns in North America that communicate the pros and cons of modular construction in terms of quality, environment, flexibility in design, and ROI. Engaging industry and academic partners in the strategic planning of research and development of modular construction is recommended to promote the implementation of research outcomes in industry, to increase collaboration between modular construction organizations and other organizations, and to offer university and training courses.

Second hypothesis: The lack of examples of past success is a barrier to increased market share

Most respondents agreed, as shown in Figure 7, that there is lack of promotional material that depicts the successes and advantages of modular construction. The respondents also agreed that there is a lack of documentation of lessons learned around the world and a gap in knowledge among owners regarding the compatibility of modular construction with different structure types and materials [30]. Moreover, there was agreement that governmentsponsored case studies and academic research that highlight obstacles and opportunities for modular construction are also lacking, and that there is a shortage of data that is readily available to manufacturers and owners to support decision making with a high level of confidence (as shown in Figure 8). Respondents recommended for the industry partner, PreFab Australia, and PreFab New Zealand to produce more publications pertaining specifically to the advantages and successes of modular construction that would serve as outreach for owners, architects, engineers, and contractors to convince them of the advantage. The respondents also recommended that the industry partner, PreFab Australia, and PreFab New Zealand increase awareness of modular construction among architects, use social media for marketing, and prepare online courses for modular construction. They also recommended institutes and universities publish more papers, highlight modular advantages in academic courses, promote modular advantages to authorities and policymakers, and collaborate with industry and organizations [30]. 


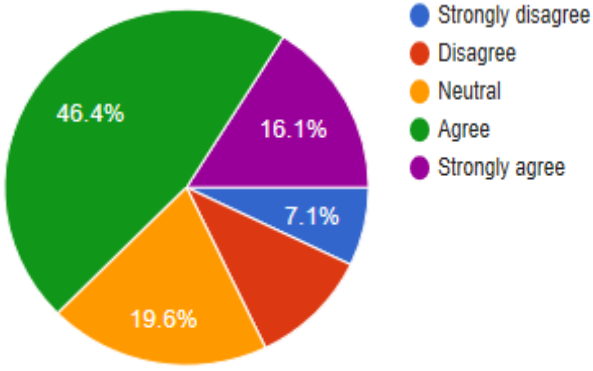

Figure 5. Percentage of respondents who agree or disagree that there is a negative stigma associated with modular and offsite construction [30].

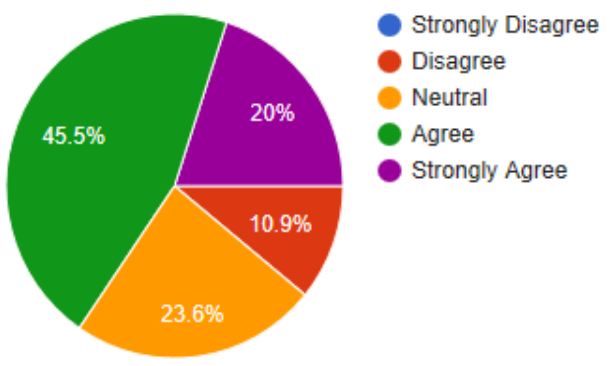

Figure 6. Percentage of respondents who agree or disagree that there is a lack of academic research on modular construction [30].

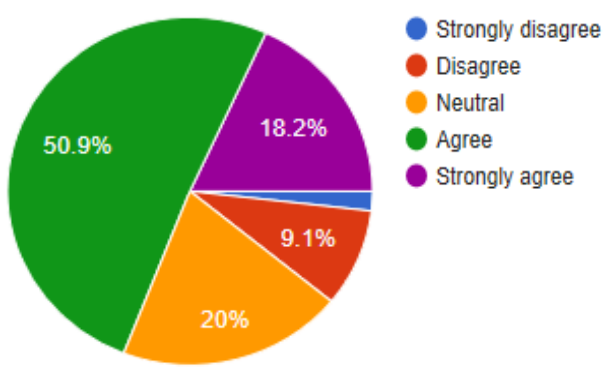

Figure 7. Percentage of respondents who agree or disagree that there is a lack of promotional materials describing the successes and advantages of modular construction [30].

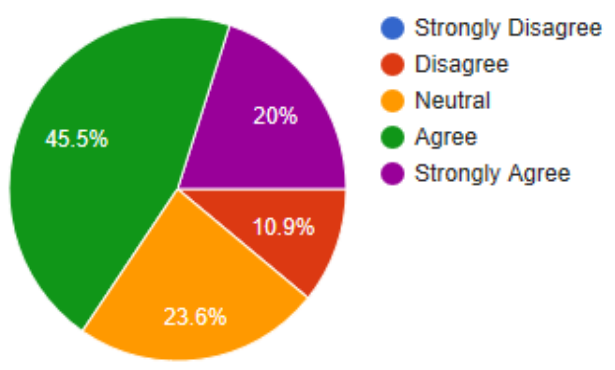

Figure 8. Percentage of respondents who agree or disagree that there is a lack of promotional materials describing the successes and advantages of modular construction [30].

\section{Third hypothesis (standards and regulations)}

The majority of respondents disagreed with the statement that existing regulations are not obstacles for the modular industry as shown in Figure 9. A large percentage of the respondents, $83.6 \%$, agreed that transportation regulations affect cost, time, and design of modular construction, as shown in Figure 10. While $74 \%$ of respondents agreed that the culture among inspectors, regulators, and operators, etc. may place an extra burden on manufacturers as shown in Figure 11, 78\% of respondents also agreed that variations in regulations among various jurisdictions complicate the delivery of modules (Figure 12). The majority of respondents, 66.7\%, agreed that regulations and by-laws should account for the different nature of the modular industry compared to conventional construction.

Respondents recommended for the industry partner, PreFab Australia, and PreFab New Zealand to support the use of a separate design code for modular construction and to contact governments at all levels to lobby for modular friendly regulations as well as to educate the inspection community with respect to modular construction. In addition to working with existing advocacy groups for construction, such as the National Association of Home Builders (NAHB), respondents recommended improved coordination with code agencies to release uniform codes that may be applicable across multiple jurisdictions that adopt modular construction. Respondents also recommended institutes and universities develop research that ties codes and standards with the theories behind modular construction while finding gaps between current standards and current practices in modular construction, all while introducing modular concepts and courses to architectural and engineering departments. Respondents also clarified that developing modular standards is more important than promotional events and they recommended organizing technical workshops to develop standards that are locally relevant and can be trusted by all stakeholders. Other respondents recommended reaching out to offer presentations to other trade and professional associations, creating events for owners, designers, contractors, and code inspectors, as well as reviewing the growth of modular construction the United Kingdom and adopting the same marketing policies that were employed there.

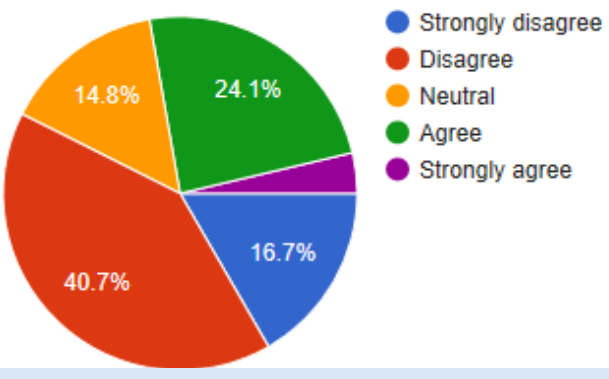

Figure 9. Percentage of respondents who agree or disagree that existing regulations are not obstacles for modular industry [31]. 


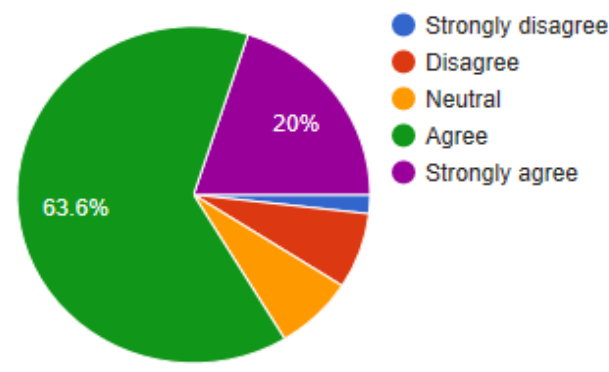

Figure 10. Percentage of respondents who agree or disagree that transportation regulations affect cost, time, and design [31].

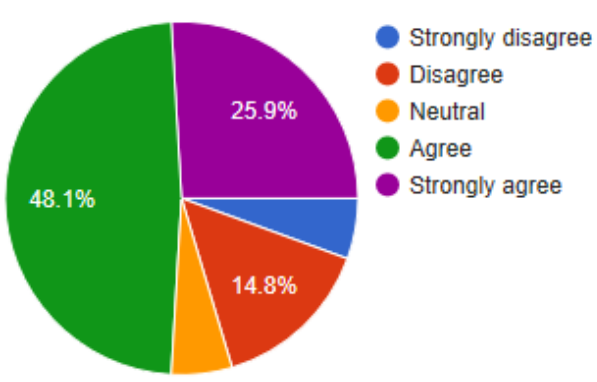

Figure 11. Percentage of respondents who agree or disagree that culture of inspectors, regulators, operators, etc. place extra burden on manufacturers [31].

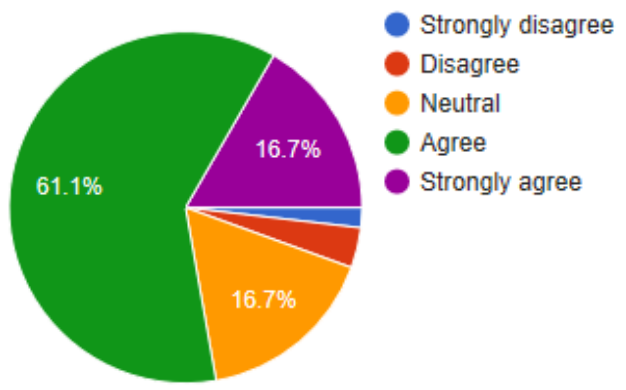

Figure 12. Percentage of respondents who agree or disagree that changes of regulations among different jurisdictions complicate delivery of modules [31].

Fourth hypothesis: Procurement strategies are a barrier to increased market share

Most respondents agreed, as shown in Figure 13, that modular construction imposes changes in perception of ownership between project stakeholders comparing to traditional construction. For instance, respondents had different opinions if the full ownership of module purchaser starts after fabrication as shown in Figure 17. They also agreed, as shown in Figure 14, that a project execution plan has to be communicated up front and incorporated into the bidding process due to the different nature of a modular project which freezes the design in the early stages of a project and has short schedules [30]. Respondents recommended for the industry partner, PreFab Australia, and PreFab New Zealand to develop codes and standards that consider procurement regulations for modular construction while increasing credibility of suppliers. It was also suggested to study the procurement strategies of solar/renewable energy industries as examples of applying innovative procurement, financing, and insurance solutions, and to implement proper supply chain strategies [30]. They also recommended institutes and universities develop new procurement methods that account for characteristics of modular construction.

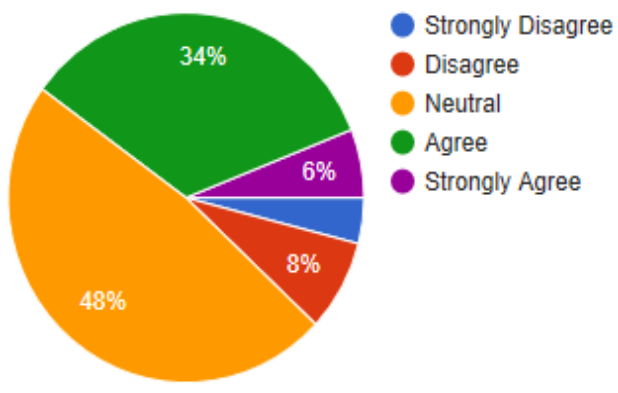

Figure 13. Percentage of respondents who agree or disagree that modular construction imposes changes in perception of ownership [31].

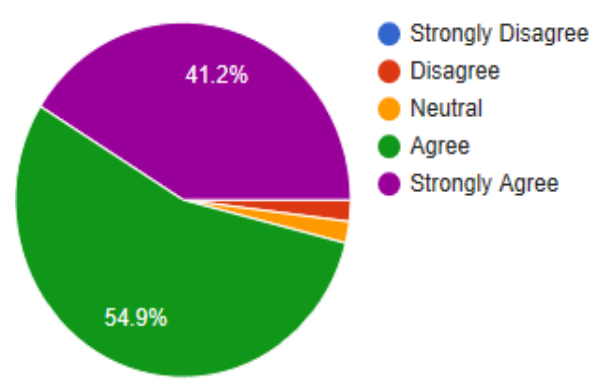

Figure 14. Percentage of respondents who agree or disagree that project execution plan has to be incorporated in bidding process [31].

Fifth hypothesis: Project financing is a barrier to increased market share

Most respondents agreed, as shown in Figure 15, that predictability of cost and schedule gives the modular industry an advantage over conventional construction, and that the lower level of risk associated with modular construction encourages stakeholders to adopt new payment methods (Figure 16). Respondents were asked about storage responsibility for modules in different scenarios, and responded as follows: (1) $52 \%$ of respondents agreed that modules belong to the owner from the moment it is fabricated, and that the owner should be responsible for the cost associated with storage (Figure 17); (2) 69\% of respondents agreed that the owner should be responsible for the cost associated with storage if the module is fabricated on time and ready to be delivered to the owner, or if, for any reason, it cannot be delivered to the site upon owner's request (Figure 18); (3) 
$54 \%$ of respondents agreed that it is the manufacturer's responsibility to pay for any cost associated with storage if the module is not assembled (Figure 19); (4) 19.6\% of respondents indicated that they have had a problem with delivered modules because they were different from design specifications leading to difficulties during the installation process (Figure 20); and (5) $76.5 \%$ of respondents agreed that the manufacturer should be held responsible for associated extra costs (e.g., storage) if the delivered module is not in full compliance with its design specifications and it does not fit at its final location onsite (Figure 21).

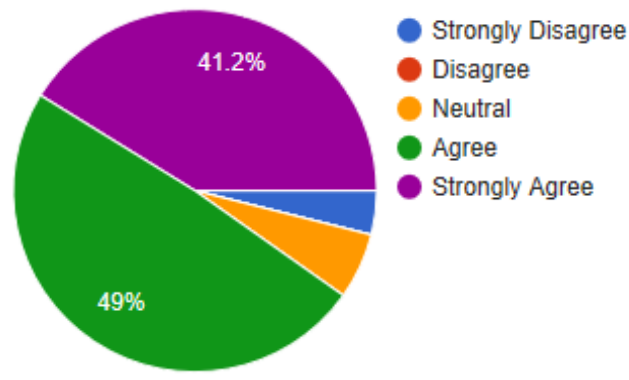

Figure 15. Percentage of respondents who agree or disagree that predictability of cost and schedule gives modular industry an advantage [31].

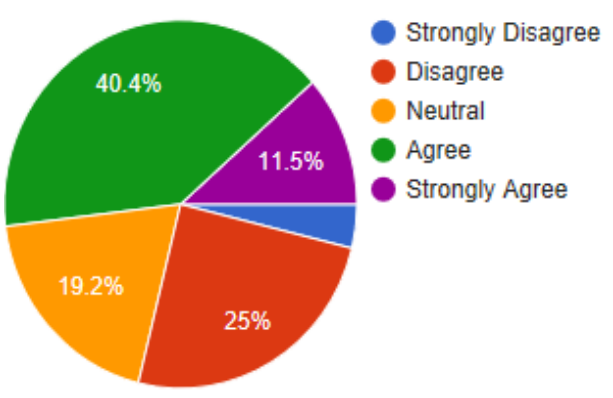

Figure 16. Percentage of respondents who agree or disagree that lower risk associated with modular construction encourages stakeholders to adopt new payment methods [31].

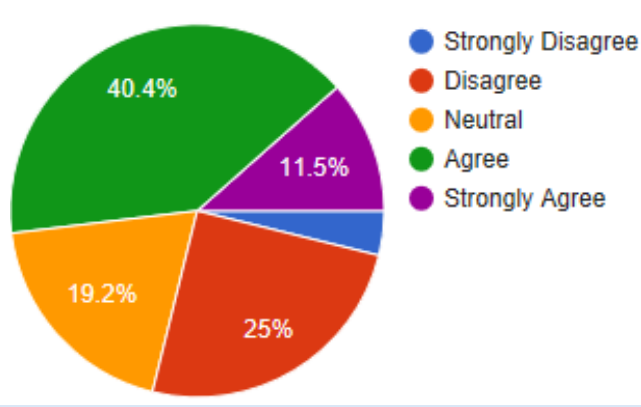

Figure 17. Percentage of respondents who agree or disagree that module belongs to owner the moment it is fabricated, and owner is responsible for storage cost [31].

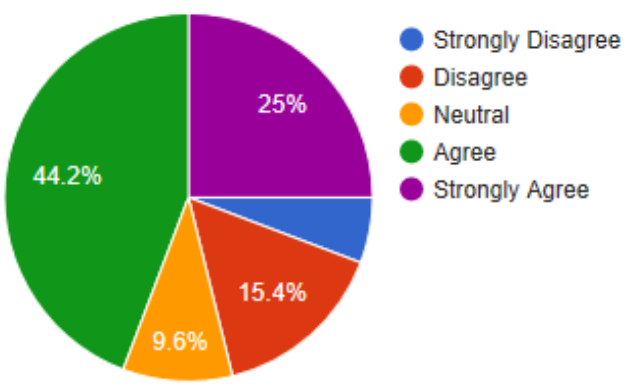

Figure 18. Percentage of respondents who agree or disagree that the owner is responsible for storage cost if module is fabricated on time but it cannot be delivered to site upon owner's request [31].

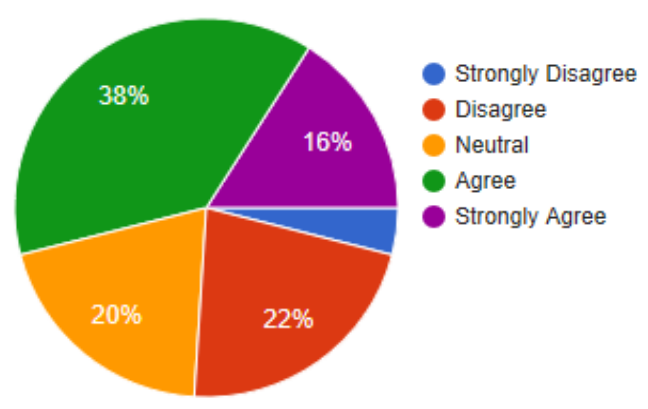

Figure 19. Percentage of respondents who agree or disagree that it is the manufacturer's responsibility to pay for any cost associated with storage if module is not assembled [31].

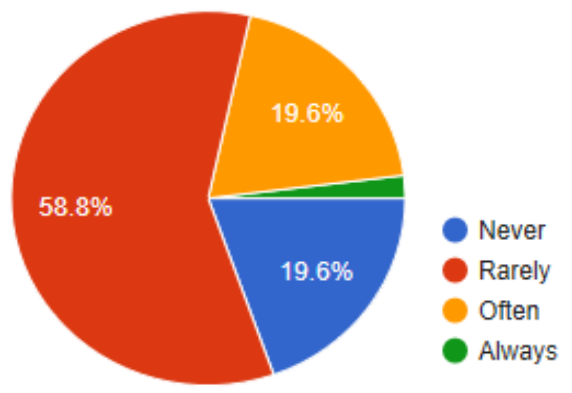

Figure 20. How often did you have a problem with modules because they were different from design leading to difficulties in installation process? [31]

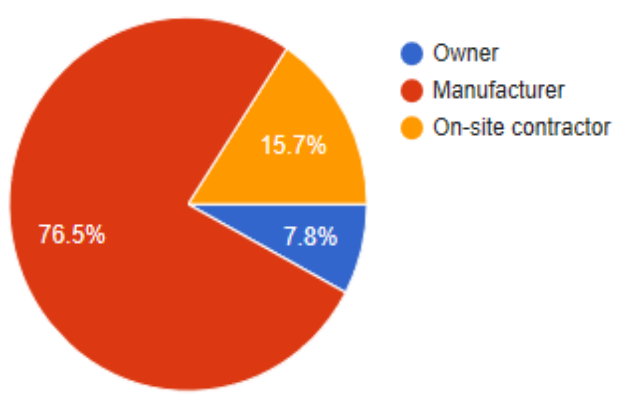

Figure 21. Who should be responsible for extra costs if a delivered module is not in full compliance with its design specifications? [31] 
Respondents were also asked to determine a percentage of the full contract price for different progress levels that would be a fair guide for determining progress payments to the manufacturer. The responses were as follows: (1) $76 \%$ of respondents agreed, as shown in Figure 22, that progress payments to the manufacturer should reach not more than $20 \%$ upon signing the contract; (2) $66.5 \%$ of respondents indicated, as shown in Figure 23, that payments to the manufacturer should not exceed $20 \%$ when design drawings are finalized; (3) $44 \%$ of respondents agreed, as shown in Figure 24, that progress payments to the manufacturer should reach no more than $50 \%$ after the modules are delivered to the construction site; and (4) $43.5 \%$ of respondents agreed, as shown in Figure 25, that progress payments to the manufacturer should reach $70 \%$ after modules are installed on site.

Respondents recommended for the industry partner, PreFab Australia, and PreFab New Zealand to cooperate with financial houses to create financial models that consider characteristics of modular construction as well as creating special conferences for lenders. They also suggested creating special lending institutions, having banks change lending policies for modular builders, lobbying insurance companies to insure modular buildings at a lower rate, as well as educating financial institutions of the risk reduction inherent in modular construction compared to stick-built construction [30]. Respondents also recommended institutes and universities design lending programs and cost management methods that account for the characteristics of modular construction, and that universities and institutions provide studies that document risk mitigation in the context of modular construction as well as educate upcoming construction leaders on the concepts of modular construction.

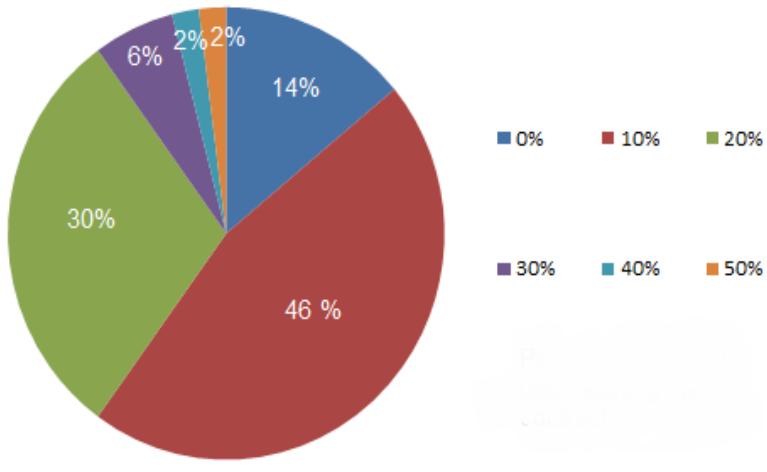

Figure 22. Percentage of respondents who indicated their preference for percentage of progress payment upon signing the contract [31].

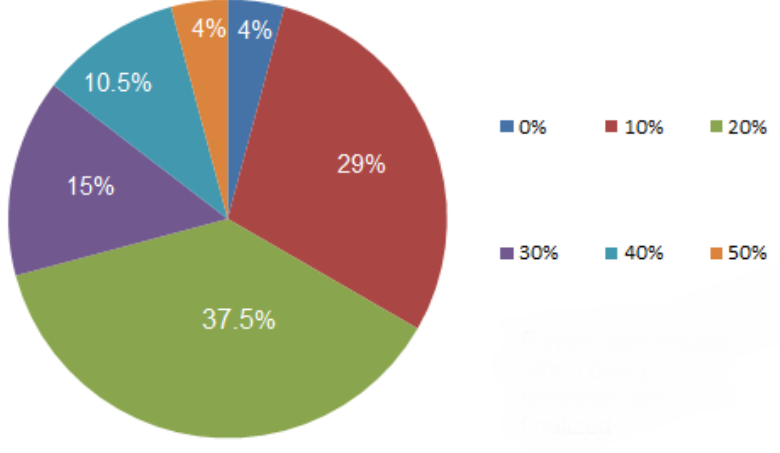

Figure 23. Percentage of respondents who indicated their preference for percentage of progress payment when design drawings are finalized [31].

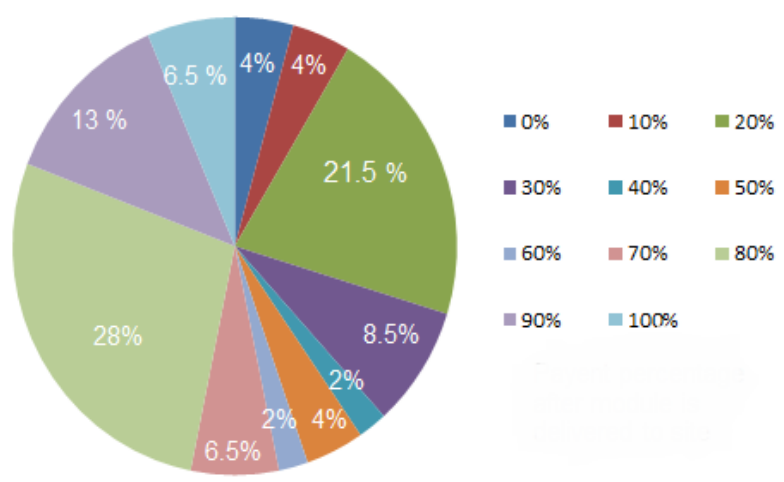

Figure 24. Percentage of respondents who indicated their preference for percentage of progress payment when module is delivered to site [31].

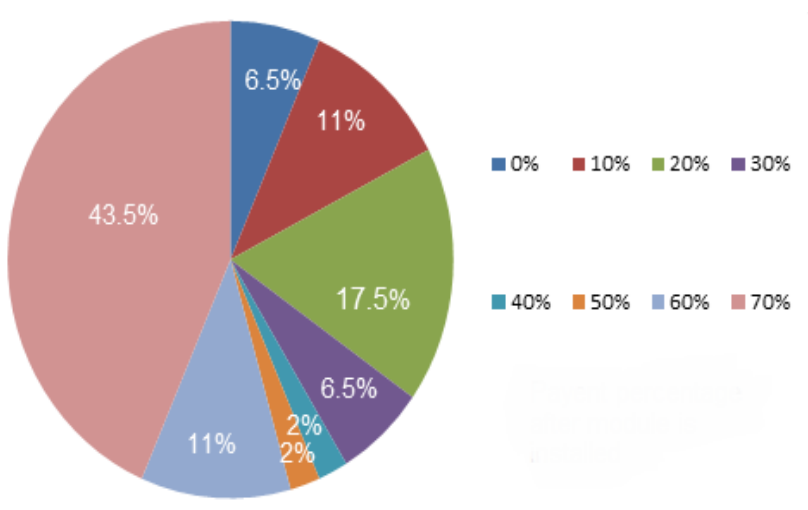

Figure 25. Percentage of respondents who indicated their preference for percentage of progress payment after modules are installed on site [31].

\section{Discussion and Conclusion}

This paper presented the findings of a questionnaire survey conducted to study characteristics of modular and offsite construction, and to analyze barriers to its growth in 11 countries. Prior to the present study, the industry partner had established the industry partner's Educational Foundation and the MBI Canadian Foundation to provide 
educational opportunities for research and training, and to provide scholarships to individuals interested in commercial modular construction. The industry partner and Clemson University announced a new online course for modular construction in May 2017 to accompany a course textbook it had developed in collaboration with the industry partner entitled Introduction to Commercial Modular Construction [30,36].

The industry partner also publishes bi-monthly magazine since 2016 entitled "Modular Advantage Magazine" which focuses on specific modular construction topics, as well as industry news, member case studies, the industry partner and company updates, and industry events. Free printed copies are mailed starting from 2020 to members of MBI, and subsequently free electronic copies are sent worldwide to 250,000 readers, including developers, architects, general contractors, and engineers. The industry partner publishes three different annual publications that analyze industry trends: (1) Permanent Modular Construction Report since 2011, which presents statistical information about growth and size of the commercial modular construction industry as well as gross sales, sales by market segment, sale of used units, industry manufacturing data, and dealer gross revenue; (2) Relocatable Building Report since 2011, which focuses on buildings designed for reusability and transportation many times to different sites, such as construction site offices, temporary schools, sales centers, and medical clinics; and (3) Canadian Commercial Modular Construction Report since 2019, which focuses on both permanent modular construction and relocatable buildings in Canada [37].

PreFab Australia started publishing a bi-monthly magazine called "Built Offsite" in October 2016, highlighting offsite construction case studies, developments, and advantages in Australia and New Zealand [38]. PreFab Australia started to organize the annual "prefabAUS Conference" in 2014, which connects professionals from around the world who represent the prefab manufacturing industry, services, procurement, research, technology, and project management. PreFab New Zealand (PrefabNZ) organizes the CoLab annual conference since 2013 to provide a venue for industry insights and to provide networking opportunities for local and international professionals. PrefabNZ also publishes a monthly newsletter since October 2017 that introduces prefabrication updates in New Zealand as well as streaming "innovation bites" online webinars at PrefabNZ's website since mid-2018 which expresses innovative ideas for prefabrication [39]. PrefabNZ organizes also "clusters" regional meetings since 2013 to provide opportunity for sharing information among prefabrication professionals [39].

The Buildoffsite organization in the United Kingdom publishes an e-magazine newsletter quarterly since June 2007 to discuss developments and challenges facing offsite construction as well as case studies of successful modular construction projects. [40]. The Buildoffsite organization also organizes the annual Offsite Manufacture Conference \& Exhibition to bring together leaders from construction, development, and infrastructure industries to drive forward the agenda of modular and offsite construction. Buildoffsite is participating as a knowledge partner in the "offsite management school project" which is a key industry-led organization that drives improvement of knowledge and skills focused on five main subjects: offsite construction, BIM, sustainability, lean construction, and management [40].

Regarding the current guidelines, standards, codes, and regulations for modular and offsite construction industry, in 2017, PreFab Australia partnered with Monash University, the Modular Construction Codes Board (MCCB), the Government of Victoria, the Australian Steel Institute, and Engineers Australia to develop a handbook for the design of modular structures [41]. In 2017, the industry partner and the ICC developed a series of modular-themed guidelines and resources to help code officials become better informed on the off-site construction process. In the United States, each state has policies and a code adoption cycle, which updates the codes every three years, for the purpose of modifying the international building code (IBC) [42]. In Canada, most provinces adopt the National Building Code, which is revised every five years. In 2019, the industry partner, together with the ICC, developed the G5-2019 guideline for the safe use of ISO intermodal shipping containers repurposed as buildings and building components [43], [44]. The industry partner and ICC are currently developing a new standard with the American National Standards Institute (ANSI 1205) for reviewing and approving modular projects [42]. In Canada, the Canadian Standards Association (CSA) standard CSA A277 identifies the certification procedure for prefabricated buildings, and provides certification requirements for the quality of manufacturing and prefabricated products. CSA A277 is the standard used for modules, panels, and prefabricated buildings constructed using any material in manufacturing facilities before being shipped to construction sites [42]. Arup prepared a report in June, 2020, on high-rise modular construction for the CSA to identify next steps to improve CSA A277 based on current challenges, opportunities to create consistency and clarity for all stakeholders [45]. The technical committee of CSA is currently reviewing the Arup report to identify steps required to modernize CSA A277 [45]. $\mathrm{CMHI}$ and the Canadian manufactured housing institute (MHICanada) created the modular construction council of the Canadian Home Builders' Association (CHBA) to monitor and participate in developing codes, standards and regulations, liaising with governmental officials, regulatory bodies, related organizations, and the public, as well as facilitating research to identify technical 
problems and supporting development of codes and standards.

There are worldwide efforts being made to overcome barriers and challenges facing modular and offsite construction. The Canadian Government, through Canada mortgage and housing corporation (CMHC), has started the rapid housing initiative (RHI) which is a \$1 billion dollar program for utilizing modular construction in addressing housing shortages for vulnerable Canadians. CMHC received 679 applications totaling $\$ 4.2$ billion for their RHI which is more than the approved $\$ 1$ billion initiative and $\mathrm{CMHC}$ is waiting to see if Canadian leaders will approve more funding for the additional requests in 2021 budget [46].

In USA, the industry partner is hosting a consensus-based process to develop a procurement guide specifically for modular builders and general contractors while engaging members of the Associated General Contractors of America (AGC) in the process [34]. This procurement guide is expected to assist project teams in issues related to lending, insurance, bonding, scope delineation, inspection, supply chain, and cost estimating which are different in modular and offsite construction, and will be included with the AGC ConsensusDocs (construction contract agreement documents and templates), and the AIA contract documents, which together represent the majority of contractual procurement arrangements for traditional construction [34]. The industry partner partnered also with NIBS and Fannie Mae to develop a toolkit to help multifamily lenders, stakeholders and developers to navigate their first modular project [47]. In $\mathrm{UK}$, the housing, communities and local government committee introduced in 2017 a white paper to parliament for the importance of supporting offsite construction to meet UK's plan for building 300,000 homes annually by mid2020s [48]. The UK government responded to this white paper in 2019 by introducing many steps for financing offsite construction using $£ 236 \mathrm{~m}$ from the home building fund [48]. Participants of the questionnaire survey recommended that social media promotion should be a key communication strategy. The industry partner, PreFab Australia, and PreFab New Zealand have already established social media pages on Facebook, LinkedIn, and Twitter to connect their members and followers and to post updates and news pertinent to modular and offsite construction market. Furthermore, it is suggested to increase the effort for outreach to keep professionals working in modular and offsite construction abreast of new developments in this field.

\section{Acknowledgements}

The authors wish to thank the Natural Sciences and Engineering Research Council of Canada (NSERC) and NRB Inc. for supporting this study through an NSERC Engage Grant. The authors also wish to thank Ms. Laurie Robert (VP Sales and Marketing, NRB Inc.) for her valuable input in the process of conducting the survey, and Mr. Steven Williams (Operations Director, MBI) and Mr. Tom Hardiman (Executive Director, MBI) for their support and cooperation in conducting the survey.

\section{References}

[1] Rausch, C., Edwards, C., and Haas, C. (2020). Benchmarking and improving dimensional quality on modular construction projects-A case study. International Journal of Industrialized Construction, 1(1), 2-21.https://doi.org/10.29173/ijic212

[2] Ghannad, P., Lee, Y.C. and Choi, J.O. (2020). Feasibility and implications of the modular construction approach for rapid post-disaster recovery. International Journal of Industrialized Construction, $\quad 1(1), \quad 64-75$. https://doi.org/10.29173/ijic220

[3] Modular Building Institute (MBI). (2015). Permanent modular construction annual report. Charlottesville, Virginia, USA, online: https://www.triumphmodular.com/wpcontent/uploads/2020/06/2015-PMC-RB-AnnualReports.pdf

[4] Pan, W., Zhang, Z. Q., Yang, Y. (2020). A Glossary of Modular Integrated Construction. The University of Hong Kong, Hong Kong.

[5] Gibb, A., Pendlebury, M., (2006). Glossary of Terms. Build Offsite. https://offsite.lboro.ac.uk/docs/Buildoffsite glossary V1.6b 2006.pdf

[6] Haas, C. T., O’Connor, J. T., Tucker, R. L., Eickmann, J. A., Fagerlund, W. (2000). Prefabrication and Preassembly Trends and Effects on the Construction Workforce. Report No. 10, Center for Construction Industry Studies, University of Texas at Austin, Austin, Texas, USA.

[7] Miller, T. D. (1998). Defining modules, modularity and modularization: evolution of the concept in a historical perspective. Proceedings of the 13th IPS Conference of Design for Integration in Manufacturing, Fuglsoe, Denmark.

[8] Tatum, C. B., Vanegas, J. A., Williams, J. M. (1987). Constructability Improvement Using Prefabrication, Preassembly, and Modularization. Report from Construction Industry Institute, University of Texas, Austin, Texas, USA.

[9] Construction Industry Institute (CII). (2002). Prefabrication, Preassembly, Modularization, and Offsite Fabrication in Industrial Construction: A Framework for Decision-Making. Report from University of Texas, Austin, TX, USA.

[10] Construction Industry Institute (CII). (2004). Prefabrication, Preassembly, Modularization, and Offsite Fabrication (PPMOF)-Instructor's Guide. Report from University of Texas, Austin, TX, USA.

[11] Schoenborn, J. M. (2012). A Case Study Approach to Identifying the Constraints and Barriers to 
Design Innovation for Modular Construction. Master of Science in Architecture, Virginia Polytechnic Institute and State University: Blacksburg, VA, USA.

[12] Lawson, M., Ogden, R., Goodier, C. (2014). Design in Modular Construction. CRC Press.

[13] Buildoffsite. (2006). Offsite construction industry survey. Report from Buildoffsite organization, 60 pages, London, UK, online: https://www.buildoffsite.com/content/uploads/2015/03/ Offsite-survey-2006.pdf

[14] Pan, W., Yang, Y., Zhang Z.Q., Chan, Y. S. (2019). Modularization for Modernization: A Strategy Paper Rethinking Hong Kong Construction. Report from The University of Hong Kong, Hong Kong. https://www.miclab.hk/mfm

[15] Pan, W., Zhang, Z. Q., Xie, M. C., Ping, T.Y. (2020). Modular Integrated Construction for Highrises: Measured Success. The University of Hong Kong, Hong Kong. https://www.miclab.hk/success

[16] The Building and Construction Authority (BCA). (2017). Design for Manufacturing and Assembly (DfMA), Prefabricated Prefinished Volumetric Construction.

https://www.bca.gov.sg/professionals/technology/others/ ppvc guidebook.pdf

[17] Pan, W., Gibb, A.G.F., Dainty, A.R.J. (2007) Perspectives of UK house builders on the use of offsite modern methods of construction. Construction Management and Economics, 25(2), 183-194. https://doi.org/10.1080/01446190600827058

[18] Pan, W., Gibb, A.G.F., Dainty, A.R.J. (2012) Strategies for Integrating the Use of Offsite Production Technologies in Housebuilding. ASCE Journal of Construction Engineering and Management, 138(11), 1331-1340, https://doi.org/10.1061/(ASCE)CO.1943-7862.0000544

[19] McGraw-Hill. (2011). Prefabrication and modularization; Increasing Productivity in the Construction Industry. Bedford, MA, USA. https://www.modular.org/htmlPage.aspx?name=McGra wHill_Prefabrication

[20] FMI. (2013). Survey results of prefabrication and modularization in construction. Raleigh, USA. https://www.fminet.com/insights/fmis-2013prefabrication-and-modularization-in-constructionsurvey/

[21] National Institute of Building Sciences. (2014). Report of the Results of Off-Site Construction Industry Survey. Washington, DC, USA. https://www.nibs.org/files/pdfs/NIBS_OSCC_SoftwareS urvey 2014.pdf

[22] Smith, R. E., Rice, T. (2015). Permanent Modular Construction: construction performance. Proceedings of Modular and Offsite Construction (MOC) Summit and 1st International Conference on the Industrialization of Construction (ICIC), Edmonton, AB, Canada, May 19-21, pp. 14-21. https://doi.org/10.29173/mocs172

[23] Smith, R. E., Rice, T. (2015). Permanent modular construction; process, practice, performance. MBI Modular Building Institute and University of Utah, Integrated Technology in Architecture Center, College of Architecture and Planning, Salt Lake City, Utah, USA. https://www.modular.org/documents/document_publicat ion/2015_Off-Site_PMC_Report.pdf

[24] Canadian Manufactured Housing Institute. (2016). CMHI Manufactured Building Survey. Ottawa, Canada.

https://www.manufacturedhomepronews.com/wpcontent/uploads/2017/06/cmhi_2015_annualCanadianSh ipmentReportManufacuredHousingDataResearchDailyB usinessNewsMHProNews.pdf

[25] Modular Building Institute (MBI). (2017). Modular Advantage for the commercial modular construction industry (Q3); RB annual statistical data. Virginia, USA. http://www.modular.org/documents/Modular_Advantage ModularAdvantage 3Q_2017_reduced.pdf

[26] Smith, R., Rupnik, I. (2018). 5 IN 5 Modular growth initiative research roadmap recommendations. Special report by Modular Building Institute. https://www.modular.org/documents/document publicat ion/2018_1019\%205in5\%20Deliverable.pdf

[27] Smith, R. E. Quale, J.D. (2017). Offsite Architecture: Constructing the Future. Routledge publications, Taylor \& Francis, New York.

[28] Razkenari, M., Fenner, A., Shojaei, A., Hakim, H., Kibert, C. (2020). Perceptions of offsite construction in the United States: An investigation of current practices. Journal of Building Engineering, $\quad 29, \quad 101138$. https://doi.org/10.1016/j.jobe.2019.101138

[29] Dodge Data and Analytics. (2020). Prefabrication and modular construction 2020: Smart market report. Special report by Dodge data and analytics and

MBI. https://www.modular.org/documents/public/PrefabModu larSmartMarketReport2020.pdf

[30] Salama T, Moselhi O, Al-Hussein M. (2018). Modular Industry Characteristics and Barriers to its Increased Market Share. Modular and Offsite Construction (MOC) Summit Proceedings, Hollywood, Florida, USA, March 22-25, pp. 8-15. https://doi.org/10.29173/mocs34

[31] Salama T, Moselhi O, Al-Hussein M. (2018). Modular Industry Characteristics \& Barriers to its Increased Market Share. Modular Building Institute. https://www.modular.org/documents/documen t_publication/Modular_Industry_Characteristics_and_Ba rrier_to_its_Increased_Market_Share.pdf 
[32] Salama, T. (2019). Optimized planning and scheduling for modular and offsite construction. $\mathrm{PhD}$ thesis, Concordia University, Montreal, Canada.

[33] Canadian Construction Innovations (CCI). (2015). Challenges and opportunities for modular construction in Canada. Workshop Summary Report, Concordia University, the Modular Building Institute, Canadian Construction Innovations, and University of Alberta. https://www.coursehero.com/file/52660662/Challengesand-Opportunities-for-Modular-Construction-inCanadapdf/

[34] Smith, R., Rupnik, I. (2018). 5 IN 5 Modular growth initiative research roadmap recommendations. Modular Building Institute (MBI). https://www.modular.org/documents/document_publicat ion/2018_1019\%205in5\%20Deliverable.pdf

[35] Smith, R. E. (2010). Prefab Architecture: A Guide to Modular Design and Construction. Wiley Publications, Hoboken, New Jersey, USA.

[36] Modular Building Institute (MBI), Piper, C. A. (2015). Introduction to Commercial Modular Construction. Virginia, USA.

[37] Website of modular building institute (MBI). https://www.modular.org/HtmlPage.aspx?name=foundat ion_new

[38] PrefabAUS. (2017). Built Offsite magazine. Boston Publishing Pty Ltd. Richmond, Victoria, Australia, Issue 6.

[39] PreFab New Zealand (PrefabNZ) website. http://www.prefabnz.com/Events

[40] Buildoffsite website, online. https://www.buildoffsite.com/newsletters/

[41] Monash University, PrefabAUS. (2017). Handbook for the Design of Modular Structures. Victoria, Australia.

[42] Modular Building Institute (MBI). (2020). Breaking down the modular building code. Online exclusive article.

https://www.modular.org/HtmlPage.aspx?name=MA-oimodular-building-

codes\&fbclid=IwAR1eEKJSWuapEM8drgDxE5Ypddg1 BXY-H4RHgOaYOyk3VN3GJmab03Fe8bk

[43] Modular Building Institute (MBI). (2019). Modular Advantage Magazine. Second Quarter 2019, Virginia, USA. http://www.modular.org/documents/Modular_Advantage /MA_Q2-19-reduced.pdf

[44] International Code Council. (2019). ICC G5-2019 Guideline for the Safe Use of ISO Intermodal Shipping Containers Repurposed as Buildings and Building Components. https://shop.iccsafe.org/icc-g52019-guideline-for-the-safe-use-of-iso-intermodelshipping-containers-repurposed-as-buildings-andbuilding-components.html
[45] Doermann J., Finzel K., Barrot J. (2020). High-rise modular construction: A review of the regulatory landscape and considerations for growth. Standards research report prepared by Arup to CSA. https://www.csagroup.org/wp-content/uploads/CSAGroup-Research-High-Rise-Modular-Construction.pdf

[46] MBI. (2021). March 2021 government affairs update.

https://www.modular.org/HtmlPage.aspx?name=MA-oiMar2021-update

[47] Fannie Mae. (2020). Multifamily Modular Construction Toolkit. Special report by Fannie Mae, MBI \& NIBS. https://multifamily.fanniemae.com/media/13576/display

[48] Salama, T., Figgess, G., Elsharawy, M., El-Sokkary, H. (2020). Financial Modeling for Modular and Offsite Construction. Proceedings of the 37th International Symposium on Automation and Robotics in Construction (ISARC 2020), Kitakyushu, https://doi.org/10.22260/ISARC2020/0149 


\section{Appendix}

Foncordia

\section{Study on: Optimized Project Delivery for a Modular Builder}

Department of Building, Civil \& Environmental Engineering (BCEE)

This questionnaire is carried out in collaboration with NRP Inc. in Canada, the Modular Building Institute (MBI) in the USA and the School of Building Science and Engineering at the University of Alberta in Canada. The information collected will be treated strictly confidential and will be used for academic research purposes.

This questionnaire is divided into two parts. The first part addresses the characteristics of modular construction, while the second focuses on five issues emanated from the workshop on "challenges and opportunities for modular construction in Canada" held in Montreal on October 2015 to analyze barriers to growth of modular construction in Canada.

Please state whether you are interested to receive a copy of the finding of this questionnaire or not. If yes, please write your email: (n.

\section{PART (1): Industry characteristics}

1- What type of material used in fabrication and production of modules? (Please mark all that apply)

Steel

Wood

Concrete

Other (please specify .....

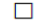

$\square$

$\square$

2- What type of modules you produce? (Please mark all that apply)

Modular construction (i.e. volumetric)

Panclized construction

Hybrid construction

Prefabricated components and elements

Bathroom pods

Other (please specify

3- What type of modular construction project?

Residential (Condominium, duplex, villa, etc...)

Institutional (College, school, library, etc...)

Commercial buildings (Hotel, Office, Restaurant, etc...)

Medical buildings (Hospital, nursing Home, quarantine, etc...)

4- What is the volume of sales (dollar value of business) for modular construction of your company over last 5 years?

$2012(\$) \quad 2013(\$) 2014(\$)$

5 - Which party is responsible for the following activities in your modular projects?

Note: If one activity is shared between two parties, please indicate the percentage of work that each party is responsible for

(MC: Modular Company (manufacturer). GC: General contractor (onsite), DF: Design firm.

Activity

Architectural design

Mechanical, electrical and

plumbing design (MEP)

Structural modular desion

Manufacturing

Transportation

Site preparation

Foundation

Setting modules onsite

Architectural finishes

Mechanical and electrical

installation

Final services connection
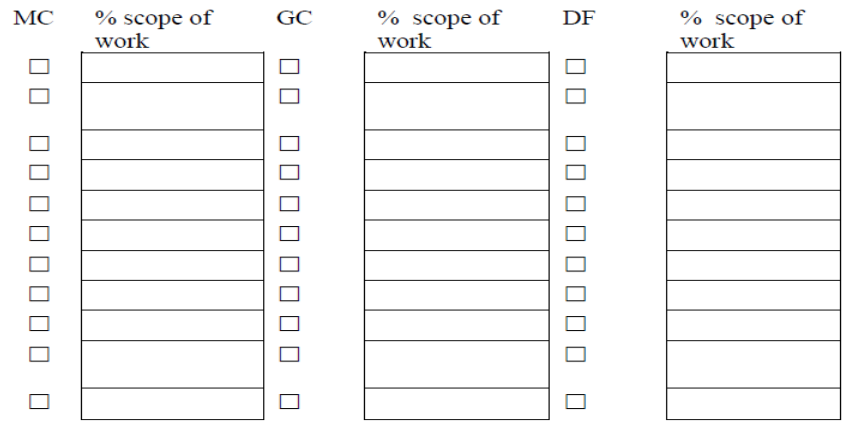

6-What is the scheduling software/method used in your company?

MS project

Primavera

Simulation software

Other (please specify

7- Are the ousite aud offsite

Yes

No

8- Is there any time study conducted to calculate productivity rates for your offsite and onsite operations?

Offsite operations only

Onsite operations only

Offsite and Onsite operations

Neither

9- Is BIM used in your company? If not, go to Part 2 
10- Which BIM software system is used in your company?

Revit

Bentley

ArchicAD

Other (please specify

11- What BIM based applications are used in your company?

Renderings for sales presentations

Scheduling

Cost estimation

Clash detection

Heat loss/gain analysis

Structural analysis

Other (please specify

12- In which project phase BIM is used your company?

Design

Computer Numeric Control (CNC) material processing for manufacturing

Monitoring for onsite activities (handling, erection, etc...)

Other (please specify

13- What future applications of BIM you are considering in your company?

$3 \mathrm{D}$ printing technology

$3 \mathrm{D}$ point cloud scanning

Computer Numeric Control (CNC) material processing for manufacturing

Virtual reality (VR) goggles

RFIDs (Radio-Frequency Identification)

Other (please specify

14- Which Project Delivery System is commonly used?

Design- Bid-Build (DBB)

Design-Bid-Build (DB)

Construction Management at Risk (CMAR)

Integrated Project Delivery (IPD)

15- What is the commonly used procurement method?

Lower bidder

Best qualified bidder based on 2-envelop bidding system

Best value (combination of 1 and 2 and negotiation)

Other (please specify $\ldots \ldots \ldots \ldots \ldots \ldots \ldots \ldots \ldots \ldots \ldots \ldots \ldots \ldots \ldots$.

Fixed Price or Lump Sum (LS)

Guaranteed Maximum Price (GMP)

Cost Plus Fixed Fee

Cost Plus Incentive Fee

Cost Plus Award Fee

Time Spent

Time and Materials

Other (please specify

17- What is the total square footage of your project?

18- What are the obstacles and difficulties that you faced on your project?

Contractors experience is not enough in applying modularization concepts

Module envelope limitation (dimensions limitation) restricted architectural design

design scope was not be frozen early in project schedule

Selected project delivery system was not suitable for the project

Scheduling method utilized was not suitable for the project

Onsite and offsite schedules were not synchronized

Other (please specify

19- What is the commonly experienced distance between manufacturing facility and project construction site?

Please specify: from ..... km to .... km

20- What is the average transportation cost per module square footage?

21- What is the average transportation cost for the following trucks on your project?

standard flatbed trailer

single-drop deck

double-drop deck

22- What is commonly used crane type in lifting modules on your projects?

Truck mounted hydraulic crane

Crawler crane

fixed tower crane

Other (please sp

23- How many modules the cranes lift per day onsite (daily placing rate)?

24- What is the average lifting capacity of the used crane?

0 to 25 tons

25 to 50 tons

50 to 75 tons

75 to 100 tons

Other (please specify

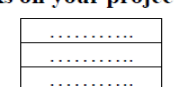

25- How is the module

Roof lifting lugs

Slings and spreaders 


\section{PART (2): Barriers to increased market share}

Hypothesis: (Negative stigma) There is a negative stigma associated with modular and offsite construction, as well as a misconception that modular is intended primarily for temporary, single-storey applications

1. Do you agree with the following statement: "There is a negative stigma associated with modular and offsite construction"?

Strongly Agree Agree Neutral Disagree Strongly Disagree

2. Do you agree with the following statement: "There is a misconception that modular is intended primarily for temporary, single-storey applications"?

$\begin{array}{llll}\text { Strongly Agree } & \text { Agree } & \text { Neutral } & \text { Disagree }\end{array}$

3. The significant advantages modular construction offers are not communicated properly with owners.

Strongly Agree Agree Neutral Disagree Strongly Disagree

4. There is a shortage of well-designed marketing campaigns conducted by modular institutions and manufactures.

Strongly Agree Agree Neutral Disagree Strongly Disagree

5. Owners are not familiar with the different products offered by the modular industry

$\begin{array}{llll}\text { Strongly Agree } & \text { Agree } & \text { Neutral } & \text { Disagree }\end{array}$

6. Due to the focus of modular manufacturers on local markets, the modular industry lacks large scale partnerships and related market share.

Strongly Agree $\quad$ Agree Neutral Disagree Strongly Disagree

$\square \quad \square \quad \square \quad \square \quad \square$

7. There is a lack of academic research that highlights the advantages of modular construction in comparison with the conventional construction methods.

Strongly Agree $\quad$ Agree $\quad$ Neutral $\quad$ Disagree $\quad$ Strongly Disagree

. Modular manufacturers and institutions should organize regular facility visits open to the public to increase awareness

$\begin{array}{llll}\text { Strongly Agree } & \text { Agree } & \text { Neutral } & \text { Disagree }\end{array}$

9. What do you recommend MBI, PreFab Australia, PreFab NewZealand and other modular-focused organizations do to remove

the stigma of modular construction?

(Check all that apply)

Organize specialized workshops $\quad \square \quad \square$

Promotional activities

$\square \quad \square$

Work on establishing partnerships

among manufacturers

$\square \quad \square$

Other (Please specify)

10. What do you recommend research institutes and universities do to remove the stigma of modular construction?

(Check all that apply)

Provide course for more exposure

Design courses that account for the

architectural aspects of $\mathrm{MC}$

Organize workshop with academic $\quad \square \quad \square$

and industry practitioners

Other (Please specify)

11. What activities, events, or specialized conferences, such as the Modular and Off-site Construction (MOC) Summit and World of Modular, must be organized, other than what exists, to remove the stigma?

12. Would publicized success stories of modular be helpful in addressing the issue raised in 11 above?

Hypothesis: (Shortage of examples of past success) There is a lack of evidence of successful implementation of modular technologies utilizing mixed use of concrete, steel, masonry, and wood for mid-rise and high-rise applications.

13. Modular construction lacks promotional materials that depict the successes and advantages.

Strongly Agree $\quad$ Agree Neutral Disagree Strongly Disagree 
14. Owners lack knowledge about the compatibility of modular construction with different structure types and materials.

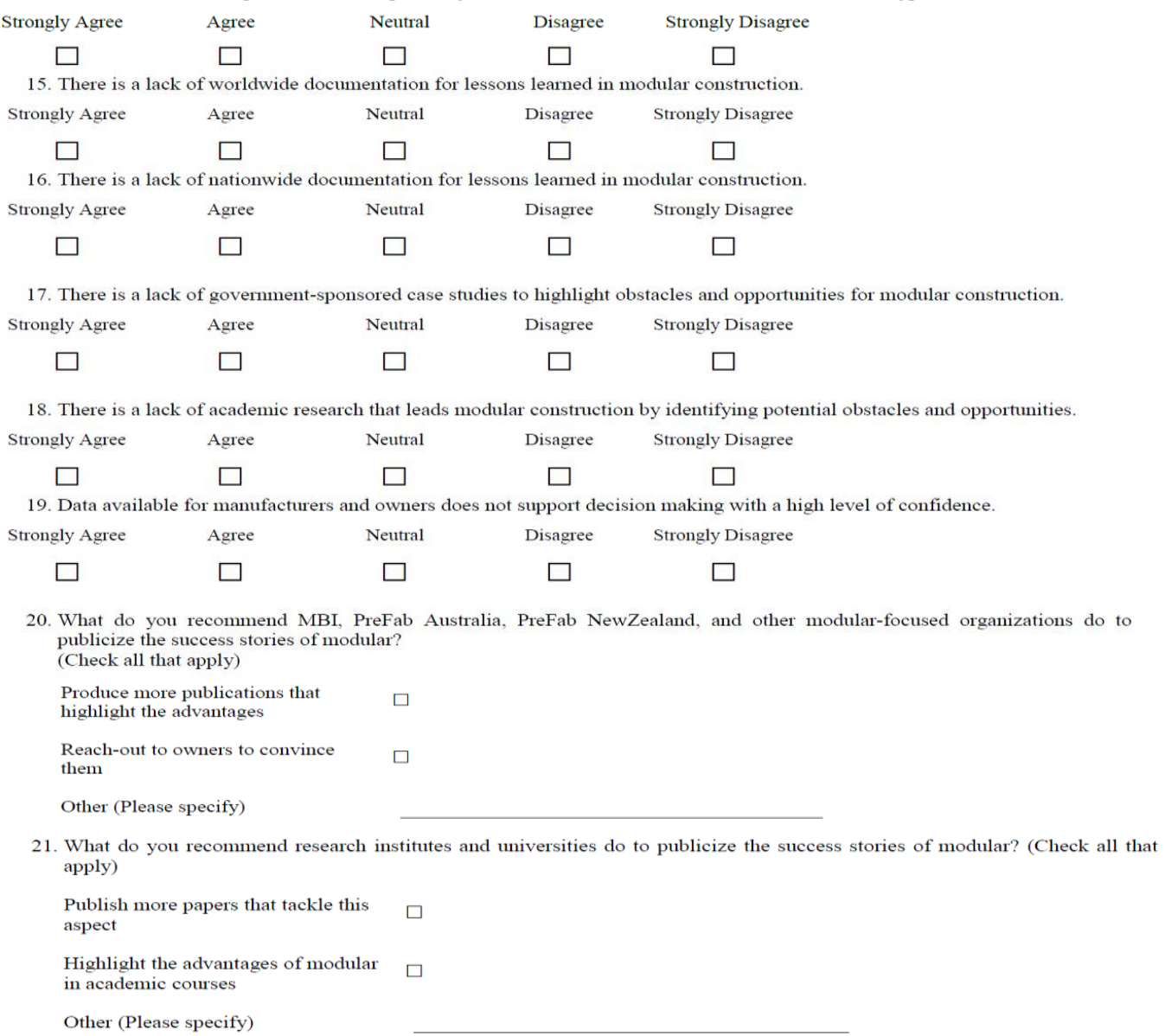

21. What do you recommend research institutes and universities do to publicize the success stories of modular? (Check all that apply)

Publish more papers that tackle this $\square$

Hypothesis: (Standards and regulations) The existing building code, bylaws, and operational standards are systemically more conducive to conventional construction practices. For example, using the current practice of onsite stick-built construction, a contractor has a variety of materials at their disposal, whereas a factory must demonstrate that it uses only certified materials.

22. Existing regulations and by-laws are not obstacles for the modular industry.

Strongly Agree $\quad$ Agree $\quad$ Neutral Disagree Strongly Disagree

23. Although the existing regulations do not affect modular construction, the culture of inspectors, regulators, operators, etc. may place an extra burden on manufacturers.

Strongly Agree $\quad$ Agree Neutral Disagree $\quad$ Strongly Disagree

24. Transportation regulations significantly affect the cost, time, design, etc. of the modules, and therefore burden the modular industry.

Strongly Agree $\quad$ Agree $\quad$ Neutral Disagree $\quad$ Strongly Disagree

25. The changes of regulations among the different jurisdictions complicate the delivery of modules.

Strongly Agree $\quad$ Agree $\quad$ Neutral Disagree $\quad$ Strongly Disagree

26. Regulations and by-laws should account for the different nature of the modular industry compared to conventional construction.

Strongly Agree $\quad$ Agree Neutral Disagree $\quad$ Strongly Disagree

$\square$ What do you recommend MBI, PreFab Australia, PreFab NewZealand, and other modular-focused organizations do to incorporate modular construction within the current standards and regulation?

28. What do you recommend research institutes and universities do to incorporate modular construction within the current standards and regulation?

29. What activities, events, or specialized conferences, such as the Modular and Off-site Construction (MOC) Summit and World of Modular, must be organized, other than what exists, to incorporate modular construction within the current standards and regulation? 
Hypothesis: (Procurement strategies which favour conventional construction technologies) At present the dominant practice for public procurement is for projects to be awarded to the lowest bidder. A value-based system for procurement may create new opportunities for modular companies that offer advantages that conventional construction cannot offer.

30. Modular construction imposes changes in the perception of ownership. For instance, the purchaser holds the full ownership of the module.

Strongly Agree $\quad$ Agree $\quad$ Neutral Disagree $\quad$ Strongly Disagree

31. Due to the nature of the modular industry, the project execution plan has to be communicated up front and incorporated in the bidding process.

$\begin{array}{llll}\text { Strongly Agree } & \text { Agree } & \text { Neutral } & \text { Disagree }\end{array}$

32. How can MBI, PreFab Australia, PreFab NewZealand, and other modular-focused organizations help to overcome the issues associated with procurement for modular construction?

3. How can research institutes and universities help to overcome the issues associated with procurement for modular construction?

34. What activities, events, or specialized conferences, such as the Modular and Off-site Construction (MOC) Summit and World of Modular, must be organized, other than what exists, to help overcome the issues associated with procurement for modular construction?

Hypothesis: (Project financing) Current practice involves the progress-based financing of projects, which inherently favours conventional construction. Public project owners recognize that modular builders will invest significant resources on a product upstream of onsite assembly (i.e., when the product is still in the factory or in storage, thus creating a cash flow challenge under the current system), and that there may be ways of employing bonds or warranties to streamline cash flow for publicly funded projects to

35. The predictability of cost and schedule gives the modular industry an advantage over the conventional construction. Strongly Agree Agree $\quad$ Neutral the modular industry an advantage over the Disagree Strongly Disagree

36. The lower level of risk associated with modular construction has to encourage stakeholders to adopt new payment methods that are different from conventional construction.

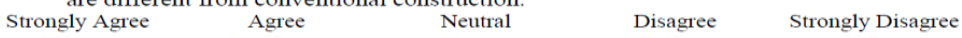

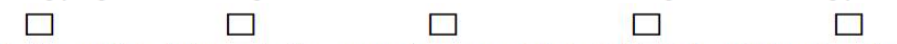

37. The module belongs to the owner the moment it is fabricated, and therefore the owner should be responsible for the cost associated with storage.

Strongly Agree with storage. Agree

Neutral Disagree Strongly Disagree

38. If the module is fabricated on time and ready to be delivered to the owner, and for any reason it cannot be delivered to the site upon owner's request, the owner should be responsible for the cost associated with storage.

$\begin{array}{llll}\text { Strongly Agree } & \text { Agree } & \text { Neutral } & \text { Disagree }\end{array}$

39. If the module is not assembled, it is the manufacturer's responsibility to pay for any cost associated with storage. Strongly Agree $\quad$ Agree $\quad$ Neutral $\quad$ Disagree Strongly Disagree

o. How often in your past projects did you have a problem with the delivered modules because they were different from the design specifications leading to difficulties in the installation process?

$$
\begin{aligned}
& \text { Never } \\
& O \text { Rarely }
\end{aligned}
$$

41. If a delivered module is not in full compliance with its design specifications and it does not fit at its final location onsite, who do you think should be held responsible for associated extra costs, e.g., storage, extra measures to fix the problem

$$
\text { ONner OManufacturer On-site contractor }
$$

42. Please indicate a percentage of the full contract price for each of the following progress levels that you think would be a fair guide for determining the progress payments to the manufacturer?

$\begin{array}{llllllllllll}\text { - "Upon signing the contract" } & 0 \% & 10 \% & 20 \% & 30 \% & 40 \% & 50 \% & 60 \% & 70 \% & 80 \% & 90 \% & 100 \%\end{array}$

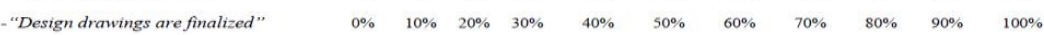

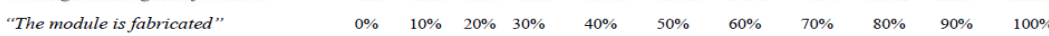

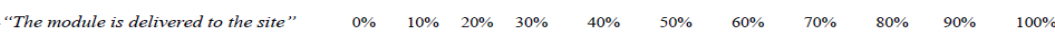

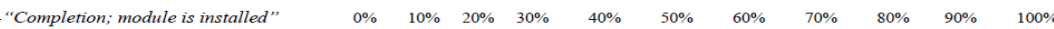

43. How can MBI, PreFab Australia, PreFab NewZealand, and other modular-focused organizations help to overcome the issue associated with project financing for modular construction?

44. How can research institutes and universities help to overcome the issues associated with project financing for modular construction?

45. What activities, events, or specialized conferences, such as the Modular and Off-site Construction (MOC) Summit and World of Modular, must be organized, other than what exists, to help to overcome the issues associated with project financing for modular construction? 